\title{
Selective use of contemporary drug-eluting stents in primary angioplasty for ST-elevation myocardial infarction: pooled analysis of COMFORTABLE AMI and EXAMINATION
}

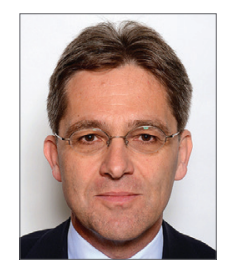

Andreas Baumbach ${ }^{1 *}, \mathrm{MD}$; Dik Heg${ }^{2}, \mathrm{PhD}$; Lorenz Räber ${ }^{3}, \mathrm{MD}$; Miodrag Ostoijc ${ }^{4}, \mathrm{MD}$; Salvatore Brugaletta ${ }^{5}$, MD, PhD; Julian W. Strange ${ }^{1}$, MD; Thomas W. Johnson ${ }^{1}$, MD; Peter Jüni' ${ }^{2}, \mathrm{MD}$; Thomas Engstrøm ${ }^{6}, \mathrm{MD}$; Patrick W. Serruys ${ }^{7}, \mathrm{MD}, \mathrm{PhD}$; Manel Sabaté, MD, PhD; Stephan Windecker², MD

1. Bristol Heart Institute, University Hospitals Bristol NHS Foundation Trust, Bristol, United Kingdom; 2. CTU Bern, Department of Clinical Research, and Institute of Social and Preventive Medicine (ISPM), University of Bern, Bern, Switzerland; 3. Department of Cardiology, Bern University Hospital, Bern, Switzerland; 4. Department of Cardiology, Medical School University of Belgrade, Belgrade, Serbia; 5. Department of Cardiology, University Hospital Clinic, Barcelona, Spain; 6. Department of Cardiology, Rigshospitalet, University of Copenhagen, Copenhagen, Denmark; 7. Department of Interventional Cardiology, Thoraxcenter, Erasmus MC, Rotterdam, The Netherlands

GUEST EDITOR: Adnan Kastrati, MD; Deutsches Herzzentrum München, Munich, Germany

This paper also includes supplementary data published online at: http://www.pcronline.com/eurointervention/110th_issue/260

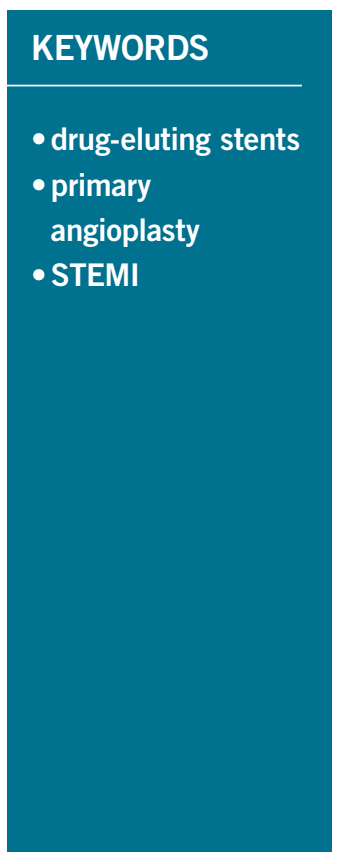

\section{Abstract}

Aims: Selective use of DES only in patients at higher risk of MACE is common practice, particularly in healthcare systems with a large premium payable for DES. We aimed to identify subgroups of patients in which the use of BMS in primary percutaneous coronary intervention (PPCI) for STEMI can still be justified.

Methods and results: We performed a patient-level pooled analysis of COMFORTABLE AMI and EXAMINATION comparing contemporary DES with BMS in PPCI. A risk score was applied using three parameters: lesion length $>15 \mathrm{~mm}$, vessel size $<3 \mathrm{~mm}$, and diabetes mellitus. Individual data were available for 2,655 patients. The incidence of MACE at one year was incrementally higher in patients with risk scores of 1 or $2 / 3$. MACE rates were lower in patients with a risk score 0 or 1 who were treated with DES $(\mathrm{p}=0.0073$ and $\mathrm{p}=0.008)$. No difference in death or reinfarction was seen between DES and BMS in any group. There was a significant reduction in TLR with DES in all three groups.

Conclusions: A score comprising vessel size, lesion length, and diabetes did not identify patients at low risk with equivalent or better results from BMS use. The results suggest that the practice of only selective use of DES in primary PCI should be discouraged.

*Corresponding author: Bristol Heart Institute, University Hospitals Bristol, Bristol, BS2 8HW, United Kingdom. E-mail:Andreas.baumbach@uhbristol.nhs.uk 


\section{Introduction}

Drug-eluting stents (DES) have been shown to reduce the risk of restenosis and related events when compared to bare metal stents $(\mathrm{BMS})^{1-5}$. The benefit over BMS is marked in some patient subgroups and lesion subsets and is less pronounced or absent in oth$\operatorname{ers}^{6-11}$. Use of multiple stents, vessel diameter and diabetes have long been identified as predictors of restenosis after stent implantation $^{12}$. In 2003, the then National Institute of Clinical Excellence (NICE) in the United Kingdom issued guidance to use DES over BMS selectively in lesions longer than $15 \mathrm{~mm}$ and vessel diameters $<3 \mathrm{~mm}$. The recommendation was based on cost-effectiveness analyses of available data, was confirmed in a revision in $2008^{13}$, and has not been revised since. Selective use of DES has become common practice, particularly in healthcare systems with limited resources. Often, additional patient factors such as the presence of diabetes and the mode of presentation are taken into account when choosing between DES and BMS ${ }^{14-16}$.

In primary percutaneous coronary intervention (PPCI) for acute ST-elevation myocardial infarction, first-generation DES have shown ambiguous results compared to BMS ${ }^{16-22}$. In the first year following implantation a reduced rate of TLR was documented; however, late stent thrombosis was seen more frequently in the following years and, overall, there was no benefit with a strategy of general use of $\mathrm{DES}^{23}$.

More recent results with newer-generation DES suggest a reduction in TLR, as well as reduced stent thrombosis, when DES are used in the treatment of STEMI. The COMFORTABLE AMI and EXAMINATION trials both reported improved outcomes in $\mathrm{PPCI}^{24,25}$. However, it remains unclear whether all patients presenting with STEMI should be treated with DES or whether differential use of DES and BMS can be justified.

It remains common practice to use DES selectively. In the recently published large-scale trials TASTE ${ }^{26}$ and TOTAL ${ }^{27}$, DES were used in less than half of the cases $(47.5 \%$ and $45 \%)$. Given the large number of PPCI performed worldwide, the selective use of DES has an important cost impact.

We postulated that we would be able to identify patient subgroups at low risk of restenosis and MACE, in which DES would not have a clinically relevant benefit over BMS in PPCI.

Editorial, see page 1566

\section{Methods}

Both COMFORTABLE AMI and EXAMINATION have been described in detail ${ }^{28,29}$.

Briefly, the multicentre COMFORTABLE AMI trial (NCT00962416) randomly assigned 1,161 patients to treatment with biolimus-eluting stents with biodegradable polymer and bare metal stents of otherwise identical design at 11 international sites. The primary endpoint was a composite of cardiac death, target vessel MI and target lesion revascularisation at one year.

The EXAMINATION trial (NCT00828087) was a multicentre, prospective, randomised, all-comer, controlled trial carried out in 12 medical centres in three countries. Patients with STEMI up to 48 hrs after the onset of symptoms requiring emergent percutaneous coronary intervention were randomly assigned (ratio 1:1) to receive an everolimus-eluting stent (EES) or a BMS. The primary endpoint was the patient-oriented combined endpoint of all-cause death, any recurrent myocardial infarction, and any revascularisation at one year, and was analysed by intention to treat. A total of 1,498 patients were randomly assigned to receive EES $(n=751)$ or BMS $(n=747)$.

The two trials had different primary endpoints. We used individually pooled data of adjudicated events, so we could align the events across the two studies.

\section{Data set}

Individual patient data were available for the COMFORTABLE and EXAMINATION trials.

Three risk criteria were defined based on the recommendations of NICE and previous analyses for differential benefits of DES over BMS $\left.^{12}: 1\right)$ small target vessel diameter $\left.(<3.0 \mathrm{~mm}), 2\right)$ long lesion length $(>15 \mathrm{~mm}$ ) (for this, the maximum stent diameter at implantation and a stent length of $\geq 20 \mathrm{~mm}$ were used), 3) presence of diabetes mellitus.

The patients were then grouped according to the risk score: 0 (absence of the above risk factors, i.e., patients without diabetes, short lesion and large target vessel), 1 (presence of one risk factor), 2 (presence of two or more risk factors $)^{30}$. The different outcomes in patients receiving either BMS or a drug-eluting stent (BES or EES) were analysed. Patients were stratified according to the randomised stent, i.e., by intention-to-treat.

\section{Statistical analyses}

Continuous data are presented as means $( \pm \mathrm{SD}$, p-values from ANOVAs) and categorical data as counts (\%, p-values from logistic regressions). Individual pooled analyses were used to assess differences in clinical outcomes comparing DES vs. BMS (intention-totreat), within each of the three risk score groups, for the pre-specified device-oriented composite endpoint of cardiac death, target vessel infarction and clinically indicated target lesion revascularisation (MACE) at one year, and for the pre-specified endpoints of all-cause death, any infarction, clinically indicated target lesion revascularisation and definite stent thrombosis at one year. Cox's regressions per endpoint, per risk group and per trial comparing DES vs. BMS for time-to-first event were used to derive effect sizes (stratified by trial when the two trials were pooled). Individual pooled Cox's regressions were used to assess a linear trend over the risk groups comparing the randomised stents, again per endpoint, stratified per trial. KaplanMeier curves are based on the pooled individual data. As a sensitivity analysis, meta-analyses and meta-regressions were performed, using a continuity correction of 0.5 in case of zero events (Online Figure 1, Online Figure 2). A two-sided p-value $<0.05$ was considered as statistically significant. Statistical analysis was performed using Stata software, version 12.1 (Stata Corp., College Station, TX, USA).

\section{Results}

Individual data were available for 2,655 patients. The baseline characteristics are summarised in Table 1. The majority had one risk factor for adverse outcomes. 
Table 1. Baseline and procedural characteristics.

\begin{tabular}{|c|c|c|c|c|c|c|c|c|c|}
\hline \multirow[b]{2}{*}{ Risk score } & \multicolumn{2}{|c|}{ None } & \multicolumn{2}{|c|}{ One } & \multicolumn{2}{|c|}{ Two or three } & \multicolumn{3}{|c|}{$p$-values } \\
\hline & $\begin{array}{c}\text { DES } \\
N=324\end{array}$ & $\begin{array}{c}\text { BMS } \\
N=350\end{array}$ & $\begin{array}{c}\text { DES } \\
N=730\end{array}$ & $\begin{array}{c}\text { BMS } \\
N=709\end{array}$ & $\begin{array}{c}\text { DES } \\
N=272\end{array}$ & $\begin{array}{c}\text { BMS } \\
N=270\end{array}$ & Score & Stent & $\begin{array}{l}\text { Score } \mathrm{x} \text { stent } \\
\text { interaction }\end{array}$ \\
\hline Age (years) & $58.61 \pm 11.46$ & $58.85 \pm 12.23$ & $60.45 \pm 12.08$ & $61.35 \pm 12.22$ & $64.21 \pm 11.50$ & $63.30 \pm 12.12$ & $<0.001$ & 0.50 & 0.32 \\
\hline Male gender, $n(\%)$ & $270(83.33)$ & $284(81.14)$ & $619(84.79)$ & $568(80.11)$ & $208(76.47)$ & $213(78.89)$ & 0.06 & 0.09 & 0.17 \\
\hline Body mass index $\left(\mathrm{kg} / \mathrm{m}^{2}\right)$ & $27.07 \pm 3.79$ & $27.40 \pm 4.04$ & $27.30 \pm 4.05$ & $27.06 \pm 3.83$ & $27.34 \pm 4.53$ & $27.93 \pm 4.09$ & 0.09 & 0.66 & 0.08 \\
\hline \multicolumn{10}{|l|}{ Cardiovascular risk factors } \\
\hline Diabetes mellitus, $n(\%)$ & $0(0.00)$ & $0(0.00)$ & 60 (8.22) & $61(8.60)$ & $161(59.41)$ & $150(55.56)$ & $<0.001$ & 0.58 & 0.72 \\
\hline Hypertension, $n$ (\%) & $133(41.05)$ & $147(42.00)$ & $326(44.66)$ & $330(46.54)$ & 167 (61.62) & 166 (61.48) & $<0.001$ & 0.56 & 0.92 \\
\hline Hypercholesterolaemia, n (\%) & $155(47.84)$ & $159(45.69)$ & $369(50.76)$ & $330(46.68)$ & $154(56.83)$ & $140(51.85)$ & 0.01 & 0.05 & 0.87 \\
\hline Current smoker, n (\%) & $174(54.04)$ & $197(56.45)$ & $349(48.01)$ & 366 (51.77) & $121(44.98)$ & $124(46.44)$ & $<0.001$ & 0.12 & 0.89 \\
\hline Family history, n (\%) & $89(28.62)$ & $73(21.99)$ & $174(24.82)$ & $163(24.11)$ & $64(25.20)$ & $62(24.51)$ & 0.87 & 0.20 & 0.33 \\
\hline Previous MI, n (\%) & $11(3.40)$ & $14(4.00)$ & $40(5.48)$ & $44(6.21)$ & $13(4.80)$ & $21(7.78)$ & 0.04 & 0.20 & 0.66 \\
\hline Previous PCI, n (\%) & $9(2.78)$ & $8(2.29)$ & $26(3.56)$ & $36(5.08)$ & $13(4.80)$ & $15(5.56)$ & 0.02 & 0.29 & 0.58 \\
\hline Previous CABG, $n(\%)$ & $1(0.31)$ & $5(1.43)$ & $7(0.96)$ & $6(0.85)$ & $5(1.85)$ & $0(0.00)$ & 0.95 & 0.68 & 0.40 \\
\hline \multicolumn{10}{|l|}{ Clinical presentation } \\
\hline Primary PCI (<12 hrs), n (\%) & $284(87.65)$ & $299(85.43)$ & 645 (88.36) & 625 (88.15) & 231 (84.93) & $235(87.04)$ & 0.74 & 0.42 & 0.62 \\
\hline Killip class II, III or IV, n (\%) & $22(6.81)$ & $24(6.88)$ & $67(9.19)$ & $64(9.05)$ & $31(11.40)$ & $25(9.26)$ & 0.03 & 0.62 & 0.79 \\
\hline LV ejection fraction (\%) & $50.48 \pm 11.21$ & $50.31 \pm 9.61$ & $50.04 \pm 10.80$ & $50.25 \pm 10.18$ & $49.23 \pm 11.06$ & $50.72 \pm 9.75$ & 0.82 & 0.40 & 0.44 \\
\hline Site of infarct-related artery, $\mathrm{n}(\%)$ & & & & & & & 0.99 & 0.84 & 0.92 \\
\hline Left main & $1(0.31)$ & $1(0.29)$ & $2(0.27)$ & $2(0.28)$ & $0(0.00)$ & $0(0.00)$ & & & \\
\hline Left anterior descending & $142(43.83)$ & 155 (44.41) & 278 (38.08) & 269 (37.94) & $129(47.43)$ & 111 (41.11) & & & \\
\hline Left circumflex & $47(14.51)$ & 49 (14.04) & $99(13.56)$ & $97(13.68)$ & $38(13.97)$ & $51(18.89)$ & & & \\
\hline Right circumflex & $134(41.36)$ & $142(40.69)$ & $349(47.81)$ & $338(47.67)$ & $103(37.87)$ & $108(40.00)$ & & & \\
\hline Saphenous vein graft & $0(0.00)$ & $2(0.57)$ & $2(0.27)$ & $3(0.42)$ & $2(0.74)$ & $0(0.00)$ & & & \\
\hline \multicolumn{10}{|c|}{ Angiographic and procedural characteristics } \\
\hline TIMI flow 0 to 2 before $\mathrm{PCl}, \mathrm{n}(\%)$ & $245(76.09)$ & $282(81.74)$ & 624 (85.71) & 588 (83.29) & $220(80.88)$ & $229(85.13)$ & 0.04 & 0.55 & 0.05 \\
\hline Thrombus aspiration, $\mathrm{n}(\%)$ & $218(67.28)$ & 246 (70.49) & $468(64.11)$ & $462(65.16)$ & $159(58.46)$ & $147(54.44)$ & $<0.001$ & 0.72 & 0.41 \\
\hline Multivessel treatment, $n(\%)$ & $2(0.62)$ & $2(0.57)$ & $49(6.71)$ & $35(4.94)$ & $9(3.31)$ & $14(5.19)$ & $<0.001$ & 0.38 & 0.27 \\
\hline Treatment of LAD, $n(\%)$ & $143(44.14)$ & $156(44.70)$ & $292(40.00)$ & $279(39.35)$ & $131(48.16)$ & 112 (41.48) & 0.95 & 0.44 & 0.40 \\
\hline \multicolumn{10}{|l|}{ Lesions and stenting } \\
\hline NNo. of lesions treated & $1.02 \pm 0.15$ & $1.01 \pm 0.14$ & $1.23 \pm 0.50$ & $1.24 \pm 0.51$ & $1.21 \pm 0.45$ & $1.23 \pm 0.46$ & $<0.001$ & 0.91 & 0.96 \\
\hline Total stent length (mm) & $16.25 \pm 2.57$ & $16.06 \pm 2.88$ & $31.66 \pm 15.07$ & $30.68 \pm 15.18$ & $33.14 \pm 14.60$ & $33.89 \pm 14.26$ & $<0.001$ & 0.24 & 0.40 \\
\hline Maximum stent diameter (mm) & $3.37 \pm 0.34$ & $3.42 \pm 1.38$ & $3.28 \pm 0.45$ & $3.28 \pm 0.59$ & $2.96 \pm 0.49$ & $2.94 \pm 0.47$ & $<0.001$ & 0.80 & 0.57 \\
\hline No. of stents implanted & $1.00 \pm 0.06$ & $0.99 \pm 0.11$ & $1.57 \pm 0.74$ & $1.54 \pm 0.83$ & $1.60 \pm 0.77$ & $1.68 \pm 0.80$ & $<0.001$ & 0.68 & 0.27 \\
\hline Direct stenting, $\mathrm{n}(\%)$ & 196 (61.44) & $217(64.97)$ & $380(52.63)$ & $355(50.35)$ & $110(40.44)$ & $91(33.83)$ & $<0.001$ & 0.42 & 0.19 \\
\hline Overlapping stents, n (\%) & $0(0.00)$ & $1(0.29)$ & $247(33.84)$ & $211(29.76)$ & $100(36.76)$ & $115(42.75)$ & $<0.001$ & 0.38 & 0.11 \\
\hline
\end{tabular}

The groups with a risk score of 1 or more showed a significantly higher incidence of diabetes, hypercholesterolaemia and hypertension $(\mathrm{p}<0.01)$, therefore identifying a generally higher risk population for cardiovascular events.

The group with a risk score of 0 showed significantly shorter lesion length, larger stent size used, and higher use of direct stenting techniques (all $\mathrm{p}<0.001)$. On average in this group one stent was used for one lesion treated.

The pharmacologic treatment in both trials was at the discretion of the operator. In patients with a risk score of 0 , more
GP IIb/IIIa inhibitors were used $(\mathrm{p}<0.001)$ and a higher use of unfractionated heparin was reported $(\mathrm{p}=0.02)$. The details are illustrated in Table 2. Online Table 1-Online Table 4 are supplied to show the data sets of Table 1 and Table 2 separately for the two trials.

The incidence of MACE at one year was incrementally higher in patients with risk scores of 1 or 2 and 3. In COMFORTABLE AMI, the patients with risk scores of 0 or 1 treated with DES had a significantly lower MACE rate compared with patients treated with BMS $(\mathrm{p}=0.0009$ for risk score 0 and $\mathrm{p}=0.035$ for risk score 1 ). 
Table 2. Medication during procedure, at discharge and follow-up.

\begin{tabular}{|c|c|c|c|c|c|c|c|c|c|}
\hline \multirow[b]{2}{*}{ Risk score } & \multicolumn{2}{|c|}{ None } & \multicolumn{2}{|c|}{ One } & \multicolumn{2}{|c|}{ Two or three } & \multicolumn{3}{|c|}{$p$-values } \\
\hline & DES & BMS & DES & BMS & DES & BMS & Score & Stent & $\begin{array}{c}\text { Score } \times \text { stent } \\
\text { interaction }\end{array}$ \\
\hline During primary PCI & $n=324$ & $n=350$ & $n=730$ & $n=708$ & $\mathrm{n}=272$ & $n=270$ & & & \\
\hline Aspirin*, n (\%) & 311 (95.99) & $335(95.71)$ & $692(94.79)$ & 672 (94.92) & $262(96.32)$ & $264(97.78)$ & 0.46 & 0.77 & 0.59 \\
\hline Clopidogrel $^{*}, \mathrm{n}(\%)$ & $291(89.81)$ & 309 (88.29) & $648(88.77)$ & $624(88.01)$ & $244(89.71)$ & $244(90.37)$ & 0.68 & 0.55 & 0.79 \\
\hline Prasugrel $^{*}, \mathrm{n}(\%)$ & $53(16.36)$ & $52(14.86)$ & $140(19.18)$ & $141(19.89)$ & $38(13.97)$ & $45(16.67)$ & 0.93 & 0.75 & 0.59 \\
\hline Any DAPT* ${ }^{*}(\%)$ & 307 (94.75) & $326(93.14)$ & 687 (94.11) & 665 (93.79) & $255(93.75)$ & 259 (95.93) & 0.16 & 0.97 & 0.07 \\
\hline UF heparin, n (\%) & 282 (87.04) & 298 (85.14) & 607 (83.15) & 596 (84.06) & 220 (80.88) & 219 (81.11) & 0.02 & 0.94 & 0.70 \\
\hline LMW heparin, $n(\%)$ & $21(6.48)$ & $20(5.71)$ & $40(5.48)$ & $45(6.35)$ & $20(7.35)$ & $25(9.26)$ & 0.14 & 0.49 & 0.66 \\
\hline Bivalirudin, n (\%) & $28(8.64)$ & $32(9.14)$ & 70 (9.59) & 68 (9.59) & $25(9.19)$ & $23(8.52)$ & 0.98 & 0.99 & 0.94 \\
\hline GP IIb/Illa antagonists, n (\%) & 154 (47.53) & 156 (44.57) & 309 (42.33) & 292 (41.18) & $103(37.87)$ & 97 (35.93) & 0.001 & 0.38 & 0.93 \\
\hline At discharge & $n=323$ & $n=347$ & $n=725$ & $\mathrm{n}=704$ & $n=268$ & $n=269$ & & & \\
\hline Aspirin, $n(\%)$ & $323(100.00)$ & 345 (99.42) & 719 (99.17) & 701 (99.57) & 267 (99.63) & 267 (99.26) & 0.50 & 1.00 & 0.63 \\
\hline Any DAPT, n (\%) & $323(100.00)$ & $343(98.85)$ & 718 (99.03) & 700 (99.57) & 265 (99.25) & 267 (99.26) & 0.75 & 0.99 & 0.80 \\
\hline At 30 days & $\mathrm{n}=308$ & $n=332$ & $n=689$ & $n=671$ & $n=248$ & $n=255$ & & & \\
\hline Aspirin, $n(\%)$ & 307 (99.68) & 327 (98.49) & 679 (98.55) & 666 (99.25) & 244 (98.39) & $254(99.61)$ & 0.90 & 0.42 & 0.12 \\
\hline Any DAPT, n (\%) & 307 (99.68) & 324 (97.59) & 675 (97.83) & 660 (98.51) & 241 (97.18) & 253 (99.22) & 0.59 & 0.62 & 0.04 \\
\hline At one year & $n=290$ & $n=322$ & $n=682$ & $n=645$ & $n=246$ & $n=249$ & & & \\
\hline Aspirin, n (\%) & 283 (97.59) & 314 (97.52) & $667(97.80)$ & 630 (97.67) & 237 (96.34) & 241 (96.79) & 0.26 & 0.89 & 0.91 \\
\hline Any DAPT, n (\%) & 271 (93.45) & $282(87.58)$ & 640 (93.84) & $573(88.84)$ & 227 (92.28) & $218(87.55)$ & 0.86 & 0.00 & 0.91 \\
\hline \multicolumn{10}{|c|}{$\begin{array}{l}\text { Depicted are counts (\%) or means } \pm \text { SD, } p \text {-values from ANOVAs or logistic regressions (NICE group linear, randomised stent). Missing data assumed no medication taken for: None/DES aspirin } \\
\text { to DAPT during PCI and aspirin at } 1 \text { year; One/DES aspirin at } 30 \text { days; One/BMS aspirin during PCI and DAPT at discharge and follow-up } 30 \text { days; Two or three/DES DAPT at discharge; } n=1 \\
\text { missing for each case respectively. }{ }^{\text {a }} p \text {-value interaction NICE risk group (linear) } \times \text { stent from the full-factorial models. *Loading dosage or already on for ASA, clopidogrel and prasugrel. DAPT } \\
\text { was ASA with clopidogrel in EXAMINATION, and ASA with clopidogrel or prasugrel in COMFORTABLE. DAPT: dual antiplatelet therapy; GP: glycoprotein; LMW: low molecular weight; } \\
\text { UF: unfractionated }\end{array}$} \\
\hline
\end{tabular}

In EXAMINATION, the rate of MACE was lower in patients treated with DES in all three groups; however, this difference was not statistically significant. The pooled analysis showed significantly lower MACE rates in patients with risk score 0 or 1 who were treated with DES ( $p=0.0073$ and $p=0.008$ ). In patients with a risk score of 2 or 3 , deemed at highest risk for restenosis and adverse cardiac events, the difference in MACE at one year between the patients treated with DES or BMS did not reach statistical significance. Details are shown in Table 3. Figure 1 provides Kaplan-Meier curves for MACE and revascularisation.

The rate of death was higher with a risk score of 1 or more; however, no difference was seen between DES and BMS in any of the groups.

The rate of reinfarction was higher with a risk score of one or more, but not different between DES and BMS in any of the groups.

Table 3. MACE at one year according to risk score.

\begin{tabular}{|c|c|c|c|c|c|c|c|c|}
\hline \multirow{2}{*}{ Study } & \multirow{2}{*}{ Risk score } & \multicolumn{2}{|c|}{ DES } & \multicolumn{2}{|c|}{ BMS } & \multirow{2}{*}{ Hazard ratio $(95 \% \mathrm{CI})$} & \multirow{2}{*}{$p$-value } & \multirow{2}{*}{ Interaction ${ }^{\mathrm{a}}$} \\
\hline & & $n$ & events (\%) & $n$ & events (\%) & & & \\
\hline \multirow[t]{3}{*}{ COMFORTABLE } & Two or three & 107 & $11(10.3)$ & 102 & $12(11.8)$ & $0.867(0.383-1.966)$ & 0.7332 & 0.013 \\
\hline & One & 320 & $13(4.1)$ & 319 & $26(8.2)$ & $0.489(0.251-0.952)$ & 0.0353 & \\
\hline & None & 148 & $0(0.0)$ & 161 & $11(6.8)$ & $0.047(0.003-0.791)^{b}$ & 0.0009 & \\
\hline \multirow[t]{3}{*}{ EXAMINATION } & Two or three & 165 & $12(7.3)$ & 168 & $17(10.1)$ & $0.708(0.338-1.482)$ & 0.3597 & 0.736 \\
\hline & One & 410 & $23(5.6)$ & 390 & $34(8.7)$ & $0.633(0.373-1.075)$ & 0.0906 & \\
\hline & None & 176 & $6(3.4)$ & 189 & $11(5.8)$ & $0.576(0.213-1.558)$ & 0.2774 & \\
\hline \multirow{3}{*}{$\begin{array}{l}\text { Individual } \\
\text { pooled data }\end{array}$} & Two or three & 272 & $23(8.5)$ & 270 & $29(10.7)$ & $0.775(0.448-1.340)$ & 0.3618 & 0.075 \\
\hline & One & 730 & $36(4.9)$ & 709 & $60(8.5)$ & $0.572(0.378-0.864)$ & 0.0080 & \\
\hline & None & 324 & $6(1.9)$ & 350 & $22(6.3)$ & $0.290(0.118-0.716)$ & 0.0073 & \\
\hline
\end{tabular}


DES

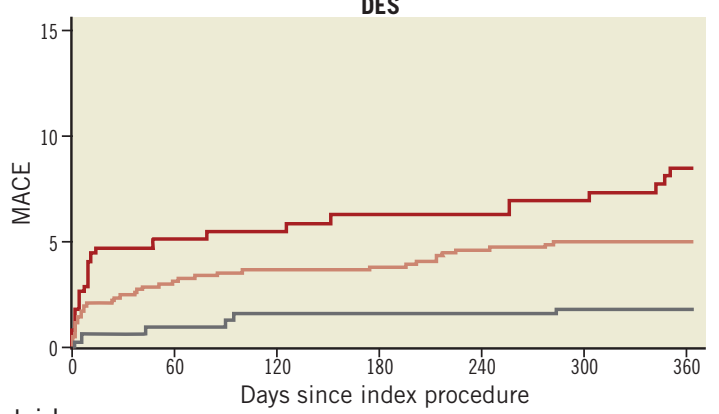

Number at risk

$\begin{array}{llllllll}\text { None } & 324 & 315 & 311 & 311 & 311 & 310 & 307 \\ \text { One } & 730 & 699 & 695 & 694 & 689 & 685 & 677 \\ \text { Two or three } & 272 & 256 & 255 & 253 & 253 & 251 & 244\end{array}$

DES

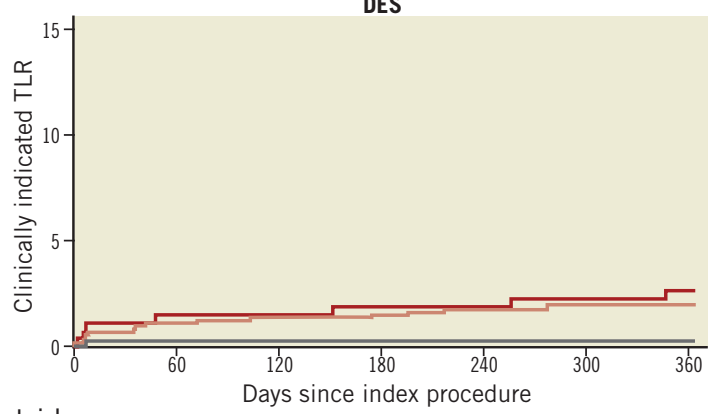

Number at risk

$\begin{array}{llllllll}\text { None } & 324 & 317 & 315 & 315 & 315 & 315 & 312\end{array}$

$\begin{array}{llllllll}\text { One } & 730 & 710 & 708 & 707 & 703 & 700 & 691\end{array}$

$\begin{array}{lllllll}\text { Two or three } & 272 & 261 & 261 & 259 & 259 & 258\end{array}$

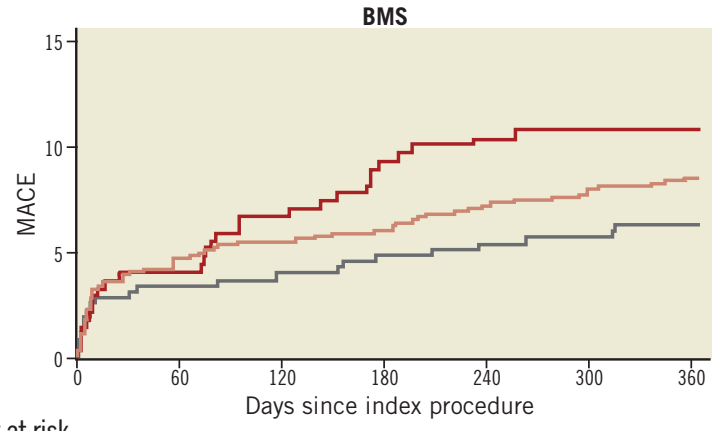

Number at risk

$\begin{array}{llllllll}\text { None } & 350 & 336 & 333 & 330 & 328 & 326 & 321\end{array}$ $\begin{array}{llllllll}\text { One } & 709 & 666 & 660 & 656 & 648 & 643 & 631\end{array}$ $\begin{array}{lllllll}\text { Two or three } 270 & 256 & 249 & 242 & 238 & 237 & 235\end{array}$

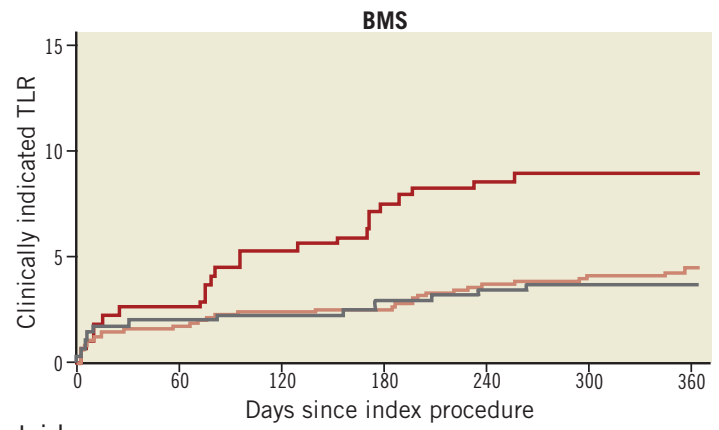

Number at risk

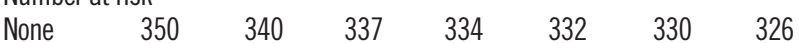

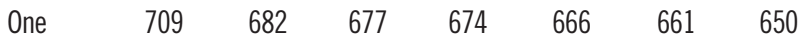

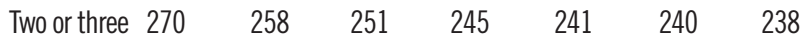

Figure 1. Major adverse cardiac events (MACE) and clinically driven target lesion revascularisation (TLR) at one year for the three risk score groups (0: grey, 1: pink, 2/3: red) and separately for drug-eluting stents (DES) and bare metal stents (BMS) used for primary angioplasty.

The rate of clinically indicated target lesion revascularisation (TLR) was lower in patients with a score of 0 . There was a significant reduction in TLR with DES in all three risk score groups. Patients without diabetes, large vessel diameters and short lesions (risk score 0) still derived a benefit from a lower TLR when treated with DES $(0.3 \%$ vs. $3.7 \%, \mathrm{p}=0.0161)$. Stent thrombosis was lower with the use of DES in all risk score groups. Table 4 gives details of clinical outcomes according to treatment and risk score.

A further analysis looking at the three risk criteria individually in relation to clinical endpoints is illustrated in Figure 2. Individual

Table 4. Individual pooled analysis of clinical outcomes at one year comparing DES vs. BMS in the three risk score groups.

\begin{tabular}{|c|c|c|c|c|c|c|c|c|}
\hline \multirow{2}{*}{ Outcome } & \multirow{2}{*}{ Risk score } & \multicolumn{2}{|c|}{ DES } & \multicolumn{2}{|c|}{ BMS } & \multirow{2}{*}{ Hazard ratio ( $95 \%$ CI) } & \multirow{2}{*}{$p$-value } & \multirow{2}{*}{$\begin{array}{c}p \text {-value } \\
\text { interaction }^{\text {a }}\end{array}$} \\
\hline & & $\mathbf{n}$ & events (\%) & n & events (\%) & & & \\
\hline \multirow[t]{3}{*}{ Death } & Two or three & 272 & $17(6.3)$ & 270 & $9(3.3)$ & $1.886(0.840-4.230)$ & 0.1240 & 0.033 \\
\hline & One & 730 & $21(2.9)$ & 709 & 28 (3.9) & $0.724(0.411-1.275)$ & 0.2637 & \\
\hline & None & 324 & $6(1.9)$ & 350 & $12(3.4)$ & $0.541(0.203-1.440)$ & 0.2186 & \\
\hline \multirow{3}{*}{$\begin{array}{l}\text { Stent } \\
\text { thrombosis }\end{array}$} & Two or three & 272 & $3(1.1)$ & 270 & $6(2.2)$ & $0.489(0.122-1.956)$ & 0.3120 & 0.518 \\
\hline & One & 730 & $5(0.7)$ & 709 & $15(2.1)$ & $0.319(0.116-0.879)$ & 0.0271 & \\
\hline & None & 324 & $1(0.3)$ & 350 & $5(1.4)$ & $0.216(0.025-1.848)$ & 0.1617 & \\
\hline \multirow[t]{3}{*}{ Reinfarction } & Two or three & 272 & $7(2.6)$ & 270 & $12(4.4)$ & $0.570(0.225-1.449)$ & 0.2377 & 0.955 \\
\hline & One & 730 & $11(1.5)$ & 709 & $18(2.5)$ & $0.588(0.278-1.246)$ & 0.1658 & \\
\hline & None & 324 & $3(0.9)$ & 350 & $6(1.7)$ & $0.540(0.135-2.159)$ & 0.3835 & \\
\hline \multirow[t]{3}{*}{ TLR } & Two or three & 272 & $7(2.6)$ & 270 & $24(8.9)$ & $0.282(0.121-0.654)$ & 0.0032 & 0.555 \\
\hline & One & 730 & $14(1.9)$ & 709 & $31(4.4)$ & $0.433(0.230-0.813)$ & 0.0093 & \\
\hline & None & 324 & $1(0.3)$ & 350 & $13(3.7)$ & $0.082(0.011-0.629)$ & 0.0161 & \\
\hline
\end{tabular}




\begin{tabular}{|c|c|c|c|c|c|c|c|}
\hline Outcome & $\begin{array}{l}\text { Events/patients } \\
\text { DES }\end{array}$ & $\begin{array}{l}\text { Events/patients } \\
\text { BMS }\end{array}$ & $\begin{array}{rrrrr}.05 & .1 & .25 & .5 & 1 \\
\end{array}$ & 124 & $\begin{array}{c}\text { Hazard ratio } \\
(95 \% \text { Cl) }\end{array}$ & $p$-value ${ }^{a}$ & $\begin{array}{c}p \text {-value } \\
\text { trend }^{\mathrm{b}}\end{array}$ \\
\hline \multicolumn{8}{|l|}{ MACE } \\
\hline Diabetes - yes & $21 / 221$ & $21 / 211$ & $\longmapsto$ & & $0.959(0.524-1.758)$ & 0.893 & 0.062 \\
\hline Diabetes - no & $44 / 1,105$ & $90 / 1,118$ & $H$ He & & $0.485(0.339-0.696)$ & $<0.001$ & \\
\hline Small vessel - yes & $12 / 248$ & $25 / 265$ & $\longmapsto$ & & $0.501(0.252-0.997)$ & 0.049 & 0.666 \\
\hline Small vessel - no & $53 / 1,078$ & $86 / 1,064$ & $\vdash \boldsymbol{H}$ & & $0.598(0.425-0.843)$ & 0.003 & \\
\hline Long lesion - yes & $51 / 834$ & $74 / 800$ & $H$ & & $0.649(0.454-0.927)$ & 0.017 & 0.183 \\
\hline Long lesion - no & $14 / 492$ & $37 / 529$ & $\longmapsto$ & & $0.398(0.215-0.736)$ & 0.003 & \\
\hline \multicolumn{8}{|l|}{ Death } \\
\hline Diabetes - yes & $17 / 221$ & $10 / 211$ & & $\longrightarrow$ & $1.679(0.768-3.670)$ & 0.194 & 0.067 \\
\hline Diabetes - no & $27 / 1,105$ & $39 / 1,118$ & $\mapsto$ & & $0.698(0.427-1.140)$ & 0.150 & \\
\hline Small vessel - yes & $7 / 248$ & $6 / 265$ & $\longmapsto$ & + & $1.240(0.417-3.690)$ & 0.699 & 0.516 \\
\hline Small vessel - no & $37 / 1,078$ & $43 / 1,064$ & $\mapsto$ & & $0.847(0.546-1.314)$ & 0.458 & \\
\hline Long lesion - yes & 33/834 & $31 / 800$ & $\mapsto$ & -1 & $1.018(0.624-1.663)$ & 0.942 & 0.340 \\
\hline Long lesion - no & $11 / 492$ & $18 / 529$ & 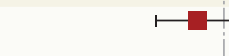 & & $0.656(0.310-1.390)$ & 0.272 & \\
\hline \multicolumn{8}{|l|}{ Reinfarction } \\
\hline Diabetes - yes & $5 / 221$ & $10 / 211$ & $\longmapsto$ & & $0.494(0.169-1.448)$ & 0.199 & 0.720 \\
\hline Diabetes - no & $16 / 1,105$ & $26 / 1,118$ & $\mapsto-$ & & $0.617(0.331-1.150)$ & 0.128 & \\
\hline Small vessel - yes & $4 / 248$ & 9/265 & $\longmapsto$ & & $0.465(0.143-1.511)$ & 0.203 & 0.677 \\
\hline Small vessel - no & $17 / 1,078$ & $27 / 1,064$ & $\mapsto$ & & $0.621(0.338-1.139)$ & 0.124 & \\
\hline Long lesion - yes & $16 / 834$ & $25 / 800$ & $\mapsto$ & & $0.606(0.324-1.136)$ & 0.118 & 0.738 \\
\hline Long lesion - no & $5 / 492$ & $11 / 529$ & $\longmapsto$ & +1 & $0.486(0.169-1.398)$ & 0.181 & \\
\hline \multicolumn{8}{|c|}{ TLR (clinically indicated) } \\
\hline Diabetes - yes & $5 / 221$ & $14 / 211$ & $\longmapsto$ & & $0.338(0.121-0.938)$ & 0.037 & 0.903 \\
\hline Diabetes - no & $17 / 1,105$ & $54 / 1,118$ & $\mapsto$ & & $0.313(0.182-0.540)$ & $<0.001$ & \\
\hline Small vessel - yes & $5 / 248$ & $19 / 265$ & $\longmapsto$ & & $0.276(0.103-0.740)$ & 0.010 & 0.734 \\
\hline Small vessel - no & $17 / 1,078$ & $49 / 1,064$ & $\mapsto$ & & $0.338(0.195-0.586)$ & $<0.001$ & \\
\hline Long lesion - yes & 18/834 & $48 / 800$ & $\mapsto$ & & $0.352(0.205-0.605)$ & $<0.001$ & 0.414 \\
\hline Long lesion - no & $4 / 492$ & $20 / 529$ & $\longmapsto$ & & $0.212(0.072-0.620)$ & 0.005 & \\
\hline \multicolumn{8}{|c|}{ Definite stent thrombosis } \\
\hline Diabetes - yes & $3 / 221$ & 4/211 & & & $0.747(0.167-3.346)$ & 0.703 & 0.274 \\
\hline Diabetes - no & $6 / 1,105$ & $22 / 1,118$ & $\square$ & & $0.274(0.111-0.677)$ & 0.005 & \\
\hline Small vessel - yes & $1 / 248$ & $4 / 265$ & $\longrightarrow$ & $\square$ & $0.260(0.029-2.323)$ & 0.228 & 0.801 \\
\hline Small vessel - no & $8 / 1,078$ & $22 / 1,064$ & $\longmapsto$ & & $0.357(0.159-0.803)$ & 0.013 & \\
\hline Long lesion - yes & $7 / 834$ & 19/800 & $\longmapsto$ & & $0.351(0.148-0.836)$ & 0.018 & 0.886 \\
\hline Long lesion - no & $2 / 492$ & $7 / 529$ & $\longmapsto$ & in & $0.310(0.064-1.490)$ & 0.144 & \\
\hline
\end{tabular}

Figure 2. Individual pooled analyses of clinical outcomes in the presence of individual risk factors (lesion length, vessel size and diabetes) for DES vs. BMS use. ${ }^{a}$ p-values random effects using separate Cox's regressions per outcome and per presence or absence of the risk factor (stratified by study). ${ }^{b} p$-values for the interaction between stent type and presence/absence of risk factor from the full-factorial Cox's regression (stratified by study).

risk factors did not predict a differential benefit of DES with respect to a reduction of TLR. The reduction in clinically indicated TLR was significant across all patient groups, whether individual risk factors (diabetes, long lesion, small vessel) were present or not.

The numbers needed to treat (NNT) in order to avoid one MACE with the use of DES were 21 in patients with a risk score of 0,28 in patients with a risk score of 1 , and 48 in patients with a risk score of 2 or 3 .
Numbers needed-to-treat with a DES to avoid one TLR were 30 in patients with a risk score of 0,41 in patients with a risk score of 1 and 16 in patients with a risk score of 2 or 3 .

\section{Discussion}

The major finding of this pooled analysis is that, with the use of contemporary drug-eluting stents in primary PCI, a clinical benefit over bare metal stents was seen irrespective of the presence of 
risk criteria for restenosis. The use of bare metal stents in patients without anatomical or clinical risk factors (short lesions, large vessel and absence of diabetes) was still associated with a higher rate of repeat revascularisation.

The risk of adverse events, especially revascularisation, was higher in patients with diabetes, long lesions and small arteries. The number needed-to-treat to avoid one revascularisation with a DES vs. BMS was smallest when two or more risk factors were present. Contrary to the original hypothesis, the number neededto-treat in patients without any of these criteria was still sufficient to justify the use of DES.

This is in contrast to published findings in patients receiving stents for the treatment of stable angina and a previous similar assessment in a propensity-matched analysis covering all percutaneous interventions in Ontario $^{30}$. In this study with a similar risk score approach applied to the analysis, DES were associated with significant reductions in the rate of target vessel revascularisation among patients with two or three risk factors for restenosis (i.e., presence of diabetes, small vessels $[<3 \mathrm{~mm}$ in diameter], and long lesions $[>$ or $=20 \mathrm{~mm}]$ ) but not among lower-risk patients. Only a small proportion of these patients presented with STEMI.

NICE originally recommended the selective use of DES over BMS in lesion subsets with small target vessels and long target lesions, based on the analysis of early RCT for paclitaxel-eluting stents (TAXUS ${ }^{\text {TM}}$; Boston Scientific, Marlborough, MA, USA) and sirolimus-eluting stents $\left(\right.$ CYPHER $^{\circledR}$; Cordis, Johnson \& Johnson, Miami Lakes, FL, USA). The revised guidance from 2008, again a health economic analysis and recommendation, was based on a total of 17 RCT including second-generation DES. None of the trials included patients presenting with STEMI and these patients were excluded from the guidance.

Limited data are available in the context of primary PCI. In HORIZONS-AMI ${ }^{31}$, patients presenting with STEMI were randomised to receive either a PES or a BMS (3:1 randomisation). After three years, patients who received a PES had lower rates of ischaemia-driven TLR $(9.4 \%$ vs. $15.1 \%$; $<<0.0001)$, with no significant differences in the rates of death, reinfarction, stroke or stent thrombosis ${ }^{22}$. A later analysis showed that insulin-treated diabetes mellitus (hazard ratio [HR]: 3.12), reference vessel diameter $<3.0 \mathrm{~mm}$ (HR: 2.89), and lesion length $\geq 30 \mathrm{~mm}$ (HR: 2.49) were independent predictors of 12-month TLR after BMS ${ }^{10}$. In patients with two or three of these baseline risk factors, PES use markedly reduced 12-month TLR in comparison with BMS (19.8\% vs. 8.1\%, $\mathrm{p}=0.003$ ). In patients with one of these risk factors, the 12-month rates of TLR were modestly reduced by PES (7.3\% vs. $4.3 \%$, $\mathrm{p}=0.02$ ). The 12 -month TLR rates were low and similar for both stents in patients with zero risk factors (3.3\% vs. $3.2 \%, \mathrm{p}=0.93)$.

In comparison with the presented studies, MACE rates in HORIZONS-AMI were in a similar range. The 12-month outcomes in the BMS arms were $3.5 \%$ for death in both COMFORTABLE AMI and HORIZONS-AMI, rates of reinfarction were $3.7 \%$ and $4.5 \%$, and for ischaemia-driven TLR $5.7 \%$ and $7.4 \%$, respectively.
A difference in outcome was noted in patients with no risk factors; the TLR rate in our pooled analysis demonstrated only one event $(0.3 \%)$ in the DES group. This may reflect the advantage of a newer-generation DES in comparison with PES, and explains why in this study the benefit of DES was seen in the lowest risk patients as well.

Interestingly, in this cohort of patients undergoing primary PCI, none of the individual risk factors chosen for the score predicted an increased benefit of DES over BMS. The reduction in TLR was similar, whether diabetes, small vessel size or long lesion length was present or not.

The combination of more than one risk factor did increase the absolute risk of an event. However, the increase in the TLR rate was much less steep in the DES group than in the BMS group. In the highest risk group with two or more risk factors, the TLR rate with BMS was $8.9 \%$ compared to $2.6 \%$ in the DES group.

The NNT to avoid one MACE was higher in the higherrisk score group. This is a surprising finding as we would have expected a larger benefit in patients with more risk factors. This finding points towards a weakness of the chosen risk criteria to identify benefits of DES. The patient cohort with high risk scores may have had additional patient-related factors that reduced the effect of the TLR rate on the overall MACE.

When looking at cost-effectiveness, the price difference between DES and BMS has to be taken into account ${ }^{32}$. With clinical data suggesting a benefit in all subgroups of patients, selective rather than general use of contemporary DES for PPCI can only be justified in healthcare systems with a very large premium payable for the use of DES.

\section{Limitations}

The risk criteria of length and vessel diameter in this study are derived from the diameter and lengths of the stents used, rather than QCA analysis of the target lesion and vessel. The assessment of length and diameter may be more difficult in the setting of STEMI than in elective situations, and may lead to overestimation of length of the lesion and underestimation of true vessel size. The EXAMINATION trial included patients presenting $>24$ hours following symptom onset, and patients undergoing rescue angioplasty for failed thrombolysis. Hence, the studied population is heterogeneous and the effect of late presentation and increased infarct sizes may have diminished the clinical effect of DES over BMS. Neither trial included angiographic follow-up; consequently, the reported outcomes are clinically driven and may not reflect the angiographic incidence of in-stent restenosis. The two trials used DES with absorbable and permanent polymers. We cannot exclude different results with these individual devices.

\section{Conclusions}

In this large cohort of patients undergoing primary PCI for acute ST-elevation myocardial infarction, the use of drug-eluting stents showed a clinical benefit over bare metal stents in all patient groups. Contrary to common practice, selection of BMS for 
patients without risk factors (long lesions, small vessels, diabetes) would not translate into equivalent outcomes. The selective use of DES should be discouraged.

\section{Impact on daily practice}

The use of contemporary drug-eluting stents (DES) for primary percutaneous coronary intervention (PPCI) shows a clinical benefit over bare metal stents in all patients. Routine practice should adopt the universal use of contemporary DES.

\section{Guest Editor}

This paper was guest edited by Adnan Kastrati, MD; Deutsches Herzzentrum München, Munich, Germany.

\section{Acknowledgements}

A Baumbach is supported by the Bristol NIHR Biomedical Research Unit.

\section{Conflict of interest statement}

A. Baumbach reports receiving speaker and advisory fees from Biosensors and Abbott Vascular and a research grant from Abbott Vascular. S. Windecker reports receiving research contracts to the institution from Abbott, Biotronik, Boston Scientific, Medtronic, Edwards Lifesciences, and St. Jude Medical. S. Brugaletta reports receiving speaker fees from AstraZeneca, Abbott, BioVentrix and a research grant to the institution from AstraZeneca and Menarini. The other authors have no conflicts of interest to declare. The Guest Editor holds patents related to drug-eluting stent technology.

\section{References}

1. Morice MC, Serruys PW, Sousa JE, Fajadet J, Ban Hayashi E, Perin M, Colombo A, Schuler G, Barragan P, Guagliumi G, Molnar F, Falotico R; RAVEL Study Group. Randomized Study with the Sirolimus-Coated Bx Velocity Balloon-Expandable Stent in the Treatment of Patients with de Novo Native Coronary Artery Lesions. A randomized comparison of a sirolimus-eluting stent with a standard stent for coronary revascularization. $N$ Engl J Med. 2002;346:1773-80.

2. Colombo A, Drzewiecki J, Banning A, Grube E, Hauptmann K, Silber S, Dudek D, Fort S, Schiele F, Zmudka K, Guagliumi G, Russell ME; TAXUS II Study Group. Randomized study to assess the effectiveness of slow- and moderate-release polymer-based paclitaxel-eluting stents for coronary artery lesions. Circulation. 2003;108:788-94.

3. Grube E, Silber S, Hauptmann KE, Mueller R, Buellesfeld L, Gerckens U, Russell ME. TAXUS I: six- and twelve-month results from a randomized, double-blind trial on a slow-release paclitaxeleluting stent for de novo coronary lesions. Circulation. 2003; 107:38-42.

4. Stone GW, Ellis SG, Cannon L, Mann JT, Greenberg JD, Spriggs D, O’Shaughnessy CD, DeMaio S, Hall P, Popma JJ,
Koglin J, Russell ME; TAXUS V Investigators. Comparison of a polymer-based paclitaxel-eluting stent with a bare metal stent in patients with complex coronary artery disease: a randomized controlled trial. JAMA. 2005;294:1215-23.

5. Beijk MA, Neumann FJ, Wiemer M, Grube E, Haase J, Thuesen L, Hamm C, Veldhof S, Dorange C, Serruys PW, Piek JJ. Two-year results of a durable polymer everolimus-eluting stent in de novo coronary artery stenosis (The SPIRIT FIRST Trial). EuroIntervention. 2007;3:206-12.

6. Ardissino D, Cavallini C, Bramucci E, Indolfi C, Marzocchi A, Manari A, Angeloni G, Carosio G, Bonizzoni E, Colusso S, Repetto M, Merlini PA; SES-SMART Investigators. Sirolimuseluting vs uncoated stents for prevention of restenosis in small coronary arteries: a randomized trial. JAMA. 2004;292:2727-34.

7. Steinberg DH, Mishra S, Javaid A, Slottow TL, Buch AN, Roy P, Okabe T, Smith KA, Torguson R, Xue Z, Pichard AD, Satler LF, Kent KM, Suddath WO, Waksman R. Comparison of effectiveness of bare metal stents versus drug-eluting stents in large $(>$ or $=3.5 \mathrm{~mm}$ ) coronary arteries. Am J Cardiol. 2007;99: 599-602.

8. De Luca G, Sauro R, Varricchio A, Capasso M, Lanzillo T, Manganelli F, Mariello C, Siano F, Carbone G, Pagliuca MR, Rosato G, Di Lorenzo E. Impact of diabetes on long-term outcome in STEMI patients undergoing primary angioplasty with glycoprotein IIb-IIIa inhibitors and BMS or DES. J Thromb Thrombolysis. 2010;30:133-41.

9. Gordon PC, Applegate RJ, Hermiller JB, Weinsier SB, Doostzadeh J, Cao S, Sudhir K, Lansky AJ, Stone GW. Clinical and angiographic outcomes with an everolimus-eluting stent in large coronary arteries: the SPIRIT III $4.0 \mathrm{~mm}$ registry. Catheter Cardiovasc Interv. 2010;75:179-86.

10. Stone GW, Parise H, Witzenbichler B, Kirtane A, Guagliumi G, Peruga JZ, Brodie BR, Dudek D, Mockel M, Lansky AJ, Mehran R. Selection criteria for drug-eluting versus bare-metal stents and the impact of routine angiographic follow-up: 2-year insights from the HORIZONS-AMI (Harmonizing Outcomes With Revascularization and Stents in Acute Myocardial Infarction) trial. J Am Coll Cardiol. 2010;56:1597-604.

11. Parikh SV, Luna M, Selzer F, Marroquin OC, Mulukutla SR, Abbott JD, Holper EM. Outcomes of small coronary artery stenting with bare-metal stents versus drug-eluting stents: results from the NHLBI Dynamic Registry. Catheter Cardiovasc Interv. 2014;83: 192-200.

12. Kastrati A, Schömig A, Elezi S, Schühlen H, Dirschinger J, Hadamitzky M, Wehinger A, Hausleiter J, Walter H, Neumann FJ. Predictive factors of restenosis after coronary stent placement. $\mathrm{J} \mathrm{Am}$ Coll Cardiol. 1997;30:1428-36.

13. The National Institute for Health and Care Excellence. Drugeluting stents for the treatment of coronary artery disease. Technology appraisal guidance [TA152]. https://www.nice.org.uk/ guidance/ta152.

14. Billinger M, Beutler J, Taghetchian KR, Remondino A, Wenaweser P, Cook S, Togni M, Seiler C, Stettler C, Eberli FR, 
Lüscher TF, Wandel S, Jüni P, Meier B, Windecker S. Two-year clinical outcome after implantation of sirolimus-eluting and paclitaxel-eluting stents in diabetic patients. Eur Heart J. 2008;29: 718-25

15. Iijima R, Byrne RA, Dibra A, Ndrepepa G, Spaulding C, Laarman GJ, Menichelli M, Valgimigli M, Di Lorenzo E, Kaiser C, Tierala I, Mehilli J, Suttorp MJ, Violini R, Schomig A, Kastrati A. Drug-eluting stents versus bare-metal stents in diabetic patients with ST-segment elevation acute myocardial infarction: a pooled analysis of individual patient data from seven randomized trials. Rev Esp Cardiol. 2009;62:354-64.

16. De Luca G, Dirksen MT, Spaulding C, Kelbaek H, Schalij M, Thuesen L, van der Hoeven B, Vink MA, Kaiser C, Musto C, Chechi T, Spaziani G, Diaz de la Llera LS, Pasceri V, Di Lorenzo E, Violini R, Suryapranata H, Stone GW; DESERT Cooperation. Meta-analysis comparing efficacy and safety of first generation drug-eluting stents to bare-metal stents in patients with diabetes mellitus undergoing primary percutaneous coronary intervention. Am J Cardiol. 2013;111:1295-304.

17. Steg PG, Fox KA, Eagle KA, Furman M, Van de Werf F, Montalescot G, Goodman SG, Avezum A, Huang W, Gore JM. Mortality following placement of drug-eluting and bare-metal stents for ST-segment elevation acute myocardial infarction in the Global Registry of Acute Coronary Events. Eur Heart J. 2009; 30:321-9.

18. Spaulding C, Teiger E, Commeau P, Varenne O, Bramucci E, Slama M, Beatt K, Tirouvanziam A, Polonski L, Stella PR, Clugston R, Fajadet J, de Boisgelin X, Bode C, Carrie D, Erglis A, Merkely B, Hosten S, Cebrian A, Wang P, Stoll HP, Henry P. Fouryear follow-up of TYPHOON (trial to assess the use of the CYPHer sirolimus-eluting coronary stent in acute myocardial infarction treated with ballOON angioplasty). JACC Cardiovasc Interv. 2011; 4:14-23.

19. Bangalore S, Amoroso N, Fusaro M, Kumar S, Feit F. Outcomes with various drug-eluting or bare metal stents in patients with ST-segment-elevation myocardial infarction: a mixed treatment comparison analysis of trial level data from 34068 patientyears of follow-up from randomized trials. Circ Cardiovasc Interv. 2013;6:378-90.

20. Holmvang L, Kelbaek H, Kaltoft A, Thuesen L, Lassen JF, Clemmensen P, Klovgaard L, Engstrom T, Botker HE, Saunamaki K, Krusell LR, Jorgensen E, Tilsted HH, Christiansen EH, Ravkilde J, Kober L, Kofoed KF, Terkelsen CJ, Helqvist S. Long-term outcome after drug-eluting versus bare-metal stent implantation in patients with ST-segment elevation myocardial infarction: 5 years followup from the randomized DEDICATION trial (Drug Elution and Distal Protection in Acute Myocardial Infarction). JACC Cardiovasc Interv. 2013;6:548-53.

21. Dirksen MT, Vink MA, Suttorp MJ, Tijssen JG, Patterson MS, Slagboom T, Kiemeneij F, Laarman GJ; Paclitaxel-Eluting Stent versus Conventional Stent; in Myocardial Infarction with ST-Segment Elevation (PASSION) investigators. Two year follow-up after primary PCI with a paclitaxel-eluting stent versus a bare-metal stent for acute ST-elevation myocardial infarction (the PASSION trial): a follow-up study. EuroIntervention. 2008;4: 64-70.

22. Stone GW, Witzenbichler B, Guagliumi G, Peruga JZ, Brodie BR, Dudek D, Kornowski R, Hartmann F, Gersh BJ, Pocock SJ, Dangas G, Wong SC, Fahy M, Parise H, Mehran R; HORIZONS-AMI Trial Investigators. Heparin plus a glycoprotein IIb/IIIa inhibitor versus bivalirudin monotherapy and paclitaxeleluting stents versus bare-metal stents in acute myocardial infarction (HORIZONS-AMI): final 3-year results from a multicentre, randomised controlled trial. Lancet. 2011;377:2193-204.

23. Kalesan B, Pilgrim T, Heinimann K, Raber L, Stefanini GG, Valgimigli M, da Costa BR, Mach F, Luscher TF, Meier B, Windecker S, Jüni P. Comparison of drug-eluting stents with bare metal stents in patients with ST-segment elevation myocardial infarction. Eur Heart J. 2012;33:977-87.

24. Räber L, Kelbaek H, Ostojic M, Baumbach A, Heg D, Tüller D, von Birgelen C, Roffi M, Moschovitis A, Khattab AA, Wenaweser P, Bonvini R, Pedrazzini G, Kornowski R, Weber K, Trelle S, Luscher TF, Taniwaki M, Matter CM, Meier B, Jüni P, Windecker S; COMFORTABLE AMI Trial Investigators. Effect of biolimus-eluting stents with biodegradable polymer vs bare-metal stents on cardiovascular events among patients with acute myocardial infarction: the COMFORTABLE AMI randomized trial. JAMA. 2012;308:777-87.

25. Sabate $M$, Cequier A, Iniguez A, Serra A, HernandezAntolin R, Mainar V, Valgimigli M, Tespili M, den Heijer P, Bethencourt A, Vazquez N, Gomez-Hospital JA, Baz JA, MartinYuste V, van Geuns RJ, Alfonso F, Bordes P, Tebaldi M, Masotti M, Silvestro A, Backx B, Brugaletta S, van Es GA, Serruys PW. Everolimus-eluting stent versus bare-metal stent in ST-segment elevation myocardial infarction (EXAMINATION): 1 year results of a randomised controlled trial. Lancet. 2012;380:1482-90.

26. Fröbert O, James SK; TASTE Research Group. Thrombus aspiration during myocardial infarction. $N$ Engl J Med. 2014;370:675-6.

27. Jolly SS, Cairns JA, Yusuf S, Meeks B, Pogue J, Rokoss MJ, Kedev S, Thabane L, Stankovic G, Moreno R, Gershlick A, Chowdhary S, Lavi S, Niemelä K, Steg PG, Bernat I, Xu Y, Cantor WJ, Overgaard CB, Naber CK, Cheema AN, Welsh RC, Bertrand OF, Avezum A, Bhindi R, Pancholy S, Rao SV, Natarajan MK, ten Berg JM, Shestakovska O, Gao P, Widimsky P, Dzavik V; TOTAL Investigators. Randomized trial of primary PCI with or without routine manual thrombectomy. $N$ Engl J Med. 2015;372:1389-98.

28. Sabaté M, Cequier A, Iniguez A, Serra A, HernandezAntolin R, Mainar V, Valgimigli M, Tespili M, den Heijer P, Bethencourt A, Vazquez N, Brugaletta S, Backx B, Serruys P. Rationale and design of the EXAMINATION trial: a randomised comparison between everolimus-eluting stents and cobalt-chromium bare-metal stents in ST-elevation myocardial infarction. EuroIntervention. 2011;7:977-84.

29. Räber L, Kelbaek H, Ostoijc M, Baumbach A, Tuller D, von Birgelen C, Roffi M, Pedrazzini G, Kornowski R, Weber K, Heg D, 
Matter C, Luscher T, Taniwaki M, Meier B, Juni P, Windecker S. Comparison of biolimus eluted from an erodible stent coating with bare metal stents in acute ST-elevation myocardial infarction (COMFORTABLEAMI trial): rationale and design. EuroIntervention. 2012;7:1435-43.

30. Tu JV, Bowen J, Chiu M, Ko DT, Austin PC, He Y, Hopkins R, Tarride JE, Blackhouse G, Lazzam C, Cohen EA, Goeree R. Effectiveness and safety of drug-eluting stents in Ontario. $N$ Engl $J$ Med. 2007;357:1393-402.

31. Mehran R, Lansky AJ, Witzenbichler B, Guagliumi G, Peruga JZ, Brodie BR, Dudek D, Kornowski R, Hartmann F, Gersh BJ, Pocock SJ, Wong SC, Nikolsky E, Gambone L, Vandertie L, Parise H, Dangas GD, Stone GW; HORIZONS-AMI Trial Investigators. Bivalirudin in patients undergoing primary angioplasty for acute myocardial infarction (HORIZONS-AMI): 1-year results of a randomised controlled trial. Lancet. 2009;374: 1149-59.

32. Barone-Rochette G, Machecourt J, Vanzetto G, Foote A, Quesada JL, Castelli C, Danchin N, Combescure C; EVASTENT Investigators. The favorable price evolution between bare metal stents and drug eluting stents increases the cost effectiveness of drug eluting stents. Int J Cardiol. 2013;168: 1466-71.

\section{Supplementary data}

Online Table 1. Baseline and procedural characteristics of COMFORTABLE patients.

Online Table 2. Baseline and procedural characteristics of EXAMINATION patients.

Online Table 3. Medication use at procedure, discharge and follow-up of COMFORTABLE patients.

Online Table 4. Medication use at procedure, discharge and follow-up of EXAMINATION patients.

Online Figure 1. Pooled analysis of clinical endpoints according to stent used in the three risk score groups.

Online Figure 2. Meta-analysis of clinical outcomes in the presence of individual risk factors (lesion length, vessel size and diabetes) for DES vs. BMS use.

The supplementary data are published online at: http://www.pcronline.com/ eurointervention/110th_issue/260 


\section{Supplementary data}

Online Table 1. Baseline and procedural characteristics of COMFORTABLE patients.

\begin{tabular}{|c|c|c|c|c|c|c|c|c|c|}
\hline \multirow[b]{2}{*}{ NICE risk factors } & \multicolumn{2}{|c|}{ None } & \multicolumn{2}{|c|}{ One } & \multicolumn{2}{|c|}{ Two or three } & \multicolumn{3}{|c|}{$p$-values } \\
\hline & $\begin{array}{c}\text { DES } \\
N=148\end{array}$ & $\begin{array}{c}\text { BMS } \\
\mathrm{N}=161\end{array}$ & $\begin{array}{c}\text { DES } \\
N=320\end{array}$ & $\begin{array}{c}\text { BMS } \\
N=319\end{array}$ & $\begin{array}{c}\text { DES } \\
N=107\end{array}$ & $\begin{array}{c}\text { BMS } \\
N=102\end{array}$ & NICE & Stent & $\begin{array}{l}\text { NICE } x \text { stent } \\
\text { interaction* }\end{array}$ \\
\hline Age (years) & $59.65 \pm 11.49$ & $59.25 \pm 11.76$ & $59.55 \pm 11.57$ & $60.64 \pm 11.89$ & $65.79 \pm 10.69$ & $61.53 \pm 12.14$ & $<0.001$ & 0.64 & 0.016 \\
\hline Male gender, $n(\%)$ & $120(81.08)$ & $124(77.02)$ & $266(83.13)$ & $254(79.62)$ & $77(71.96)$ & 77 (75.49) & 0.24 & 0.33 & 0.50 \\
\hline Body mass index $\left(\mathrm{kg} / \mathrm{m}^{2}\right)$ & $26.84 \pm 3.97$ & $27.34 \pm 4.07$ & $27.30 \pm 4.38$ & $26.88 \pm 3.72$ & $27.73 \pm 5.22$ & $27.88 \pm 4.79$ & 0.09 & 0.78 & 0.28 \\
\hline \multicolumn{10}{|l|}{ Cardiovascular risk factors } \\
\hline Diabetes mellitus, $n$ (\%) & $0(0.00)$ & $0(0.00)$ & $22(6.88)$ & $26(8.15)$ & $62(57.94)$ & $64(62.75)$ & $<0.001$ & 0.68 & 0.97 \\
\hline Hypertension, n (\%) & $61(41.22)$ & $63(39.13)$ & $145(45.31)$ & $136(42.63)$ & $73(68.22)$ & $66(64.71)$ & $<0.001$ & 0.31 & 0.98 \\
\hline Hypercholesterolaemia, n (\%) & $68(45.95)$ & $82(51.57)$ & $189(59.62)$ & $184(58.04)$ & $67(62.62)$ & $62(60.78)$ & 0.002 & 0.97 & 0.55 \\
\hline Current smoker, $n(\%)$ & $80(54.79)$ & $87(54.37)$ & $147(46.37)$ & $163(51.42)$ & $45(42.86)$ & 51 (51.52) & 0.08 & 0.14 & 0.58 \\
\hline $\begin{array}{l}\text { Family history of coronary artery disease, } \\
\mathrm{n}(\%)\end{array}$ & $52(35.86)$ & $48(30.77)$ & 107 (33.97) & 101 (31.86) & 34 (32.69) & $30(30.30)$ & 0.71 & 0.29 & 0.90 \\
\hline Previous myocardial infarction, $\mathrm{n}(\%)$ & $4(2.70)$ & $4(2.48)$ & $22(6.88)$ & $18(5.64)$ & $5(4.67)$ & $10(9.80)$ & 0.02 & 0.94 & 0.30 \\
\hline Previous PCI, n (\%) & $2(1.35)$ & $3(1.86)$ & $10(3.13)$ & $16(5.02)$ & $7(6.54)$ & $8(7.84)$ & 0.002 & 0.25 & 0.91 \\
\hline Previous CABG, n (\%) & $1(0.68)$ & $0(0.00)$ & $6(1.88)$ & $4(1.25)$ & $3(2.80)$ & $0(0.00)$ & 0.20 & 0.11 & \\
\hline \multicolumn{10}{|l|}{ Clinical presentation } \\
\hline Primary PCI (<12 hrs), n (\%) & 138 (93.24) & $144(89.44)$ & $294(91.88)$ & $286(89.66)$ & $98(91.59)$ & $91(89.22)$ & 0.74 & 0.12 & 0.90 \\
\hline Killip class II, III or IV, n (\%) & $8(5.41)$ & $7(4.35)$ & $25(7.81)$ & $21(6.58)$ & $7(6.54)$ & $9(8.82)$ & 0.17 & 0.68 & 0.67 \\
\hline Left ventricular ejection fraction (\%) & $48.25 \pm 10.53$ & $50.51 \pm 10.03$ & $49.08 \pm 10.69$ & $49.23 \pm 10.25$ & $48.93 \pm 10.69$ & $50.12 \pm 9.98$ & 0.88 & 0.15 & 0.36 \\
\hline Site of infarct-related artery, n (\%) & & & & & & & 0.64 & 0.90 & 0.92 \\
\hline Left main (LM) & $1(0.68)$ & $0(0.00)$ & $1(0.31)$ & $1(0.31)$ & $0(0.00)$ & $0(0.00)$ & & & \\
\hline Left anterior descending (LAD) & $68(45.95)$ & $70(43.75)$ & $113(35.31)$ & $113(35.42)$ & $45(42.06)$ & $47(46.08)$ & & & \\
\hline Left circumflex (LCX) & $21(14.19)$ & $25(15.63)$ & $45(14.06)$ & $51(15.99)$ & $16(14.95)$ & 14 (13.73) & & & \\
\hline Right circumflex (RCA) & $58(39.19)$ & $65(40.63)$ & $161(50.31)$ & $153(47.96)$ & $45(42.06)$ & $41(40.20)$ & & & \\
\hline \begin{tabular}{|l|l} 
Saphenous vein graft \\
\end{tabular} & $0(0.00)$ & $0(0.00)$ & $0(0.00)$ & $1(0.31)$ & $1(0.93)$ & $0(0.00)$ & & & \\
\hline \multicolumn{10}{|c|}{ Angiographic and procedural characteristics } \\
\hline TIMl flow 0 to 2 before $\mathrm{PCl}, \mathrm{n}(\%)$ & 117 (79.59) & $131(82.91)$ & $289(90.31)$ & $270(84.64)$ & $97(90.65)$ & $92(90.20)$ & 0.002 & 0.22 & 0.14 \\
\hline Thrombus aspiration, $\mathrm{n}(\%)$ & $97(65.54)$ & $120(75.00)$ & $189(59.06)$ & 202 (63.32) & $64(59.81)$ & $52(50.98)$ & $<0.001$ & 0.22 & 0.09 \\
\hline Multivessel treatment, $\mathrm{n}(\%)$ & $2(1.35)$ & $1(0.63)$ & $26(8.13)$ & $25(7.84)$ & $4(3.74)$ & $9(8.82)$ & 0.003 & 0.74 & 0.29 \\
\hline Treatment of LAD, $n(\%)$ & $69(46.62)$ & $71(44.38)$ & $123(38.44)$ & $120(37.62)$ & 46 (42.99) & $48(47.06)$ & 0.64 & 0.93 & 0.76 \\
\hline \multicolumn{10}{|l|}{ Lesions and stenting } \\
\hline No. of lesions treated & $1.01 \pm 0.08$ & $1.00 \pm 0.00$ & $1.21 \pm 0.50$ & $1.25 \pm 0.55$ & $1.18 \pm 0.43$ & $1.23 \pm 0.46$ & $<0.001$ & 0.29 & 0.67 \\
\hline Total stent length (mm) & $16.03 \pm 3.06$ & $15.70 \pm 3.48$ & $32.46 \pm 14.93$ & $32.06 \pm 16.84$ & $33.95 \pm 13.69$ & $35.54 \pm 16.49$ & $<0.001$ & 0.71 & 0.64 \\
\hline Maximum stent diameter (mm) & $3.37 \pm 0.34$ & $3.51 \pm 2.00$ & $3.29 \pm 0.48$ & $3.31 \pm 0.73$ & $3.00 \pm 0.49$ & $3.01 \pm 0.48$ & $<0.001$ & 0.33 & 0.62 \\
\hline No. of stents implanted & $0.99 \pm 0.08$ & $0.99 \pm 0.16$ & $1.67 \pm 0.78$ & $1.66 \pm 0.98$ & $1.68 \pm 0.81$ & $1.76 \pm 0.91$ & $<0.001$ & 0.86 & 0.71 \\
\hline Direct stenting, $n(\%)$ & $64(43.54)$ & $76(48.41)$ & 140 (43.75) & 131 (41.07) & $31(28.97)$ & $22(21.57)$ & $<0.001$ & 0.65 & 0.30 \\
\hline Overlapping stents, $n(\%)$ & $0(0.00)$ & $1(0.64)$ & $111(34.69)$ & $86(26.96)$ & $38(35.51)$ & $34(33.66)$ & $<0.001$ & 0.046 & 0.41 \\
\hline $\begin{array}{l}\text { Depicted are counts }(\%) \text { or means } \pm S D, p \text {-val } \\
\text { full-factorial models. Implanted stents criter } \\
\text { vessel diameter: } \geq 3.0 \mathrm{~mm} \rightarrow \text { maximum diam } \\
\text { implanted. }\end{array}$ & es from ANOV & logistic regr & רs (NICE grol & near, randomi & stent). ${ }^{*} p$-valu & teraction NICE & sk gro & 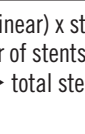 & $\begin{array}{l}\text { from the } \\
\text { planted; large } \\
\text { ength }\end{array}$ \\
\hline
\end{tabular}


Online Table 2. Baseline and procedural characteristics of EXAMINATION patients.

\begin{tabular}{|c|c|c|c|c|c|c|c|c|c|}
\hline \multirow[b]{2}{*}{ NICE risk factors } & \multicolumn{2}{|c|}{ None } & \multicolumn{2}{|c|}{ One } & \multicolumn{2}{|c|}{ Two or three } & \multicolumn{3}{|c|}{$p$-values } \\
\hline & $\begin{array}{c}\text { DES } \\
N=176\end{array}$ & $\begin{array}{c}\text { BMS } \\
N=189\end{array}$ & $\begin{array}{c}\text { DES } \\
N=410\end{array}$ & $\begin{array}{c}\text { BMS } \\
N=390\end{array}$ & $\begin{array}{c}\text { DES } \\
N=165\end{array}$ & $\begin{array}{c}\text { BMS } \\
N=168\end{array}$ & NICE & Stent & $\begin{array}{l}\text { NICE } \mathrm{x} \text { stent } \\
\text { interaction* }\end{array}$ \\
\hline Age (years) & $57.73 \pm 11.38$ & $58.50 \pm 12.64$ & $61.14 \pm 12.43$ & $61.93 \pm 12.47$ & $63.19 \pm 11.92$ & $64.38 \pm 12.01$ & $<0.001$ & 0.20 & 0.97 \\
\hline Male gender, $\mathrm{n}(\%)$ & $150(85.23)$ & $160(84.66)$ & $353(86.10)$ & $314(80.51)$ & $131(79.39)$ & $136(80.95)$ & 0.10 & 0.15 & 0.27 \\
\hline Body mass index $\left(\mathrm{kg} / \mathrm{m}^{2}\right)$ & $27.27 \pm 3.62$ & $27.46 \pm 4.02$ & $27.31 \pm 3.76$ & $27.20 \pm 3.91$ & $27.08 \pm 4.00$ & $27.96 \pm 3.59$ & 0.58 & 0.36 & 0.16 \\
\hline \multicolumn{10}{|l|}{ Cardiovascular risk factors } \\
\hline Diabetes mellitus, $n(\%)$ & $0(0.00)$ & $0(0.00)$ & $38(9.27)$ & $35(8.97)$ & $99(60.37)$ & $86(51.19)$ & $<0.001$ & 0.29 & 0.31 \\
\hline Hypertension, n (\%) & $72(40.91)$ & $84(44.44)$ & $181(44.15)$ & $194(49.74)$ & $94(57.32)$ & $100(59.52)$ & $<0.001$ & 0.09 & 0.87 \\
\hline Hypercholesterolaemia , n (\%) & $87(49.43)$ & 77 (40.74) & $180(43.90)$ & $146(37.44)$ & $87(53.05)$ & $78(46.43)$ & 0.238 & 0.01 & 0.94 \\
\hline Current smoker, $n(\%)$ & $94(53.41)$ & $110(58.20)$ & $202(49.27)$ & $203(52.05)$ & $76(46.34)$ & $73(43.45)$ & 0.004 & 0.42 & 0.57 \\
\hline $\begin{array}{l}\text { Family history of coronary artery } \\
\text { disease, } n(\%)\end{array}$ & $37(22.29)$ & $25(14.20)$ & $67(17.36)$ & $62(17.27)$ & $30(20.00)$ & $32(20.78)$ & 0.48 & 0.38 & 0.23 \\
\hline Previous myocardial infarction, $n(\%)$ & $7(3.98)$ & $10(5.29)$ & $18(4.39)$ & $26(6.67)$ & $8(4.88)$ & $11(6.55)$ & 0.53 & 0.11 & 0.96 \\
\hline Previous PCI, n (\%) & $7(3.98)$ & $5(2.65)$ & $16(3.90)$ & $20(5.13)$ & $6(3.66)$ & $7(4.17)$ & 0.65 & 0.68 & 0.59 \\
\hline Previous CABG, $n(\%)$ & $0(0.00)$ & $5(2.65)$ & $1(0.24)$ & $2(0.51)$ & 2 (1.22) & $0(0.00)$ & 0.20 & 0.22 & \\
\hline \multicolumn{10}{|l|}{ Clinical presentation } \\
\hline Primary PCl (<12 hrs), n (\%) & $146(82.95)$ & $155(82.01)$ & $351(85.61)$ & 339 (86.92) & $133(80.61)$ & $144(85.71)$ & 0.75 & 0.41 & 0.56 \\
\hline Killip class II, III or IV, n (\%) & $14(8.00)$ & $17(9.04)$ & $42(10.27)$ & $43(11.08)$ & $24(14.55)$ & $16(9.52)$ & 0.13 & 0.77 & 0.34 \\
\hline Left ventricular ejection fraction (\%) & $52.94 \pm 11.47$ & $50.08 \pm 9.15$ & $51.00 \pm 10.84$ & $51.40 \pm 9.99$ & $49.49 \pm 11.42$ & $51.17 \pm 9.60$ & 0.46 & 0.86 & 0.04 \\
\hline Site of infarct-related artery, $\mathrm{n}(\%)$ & & & & & & & 0.72 & 0.71 & 0.71 \\
\hline Left main (LM) & $0(0.00)$ & $1(0.53)$ & $1(0.24)$ & $1(0.26)$ & $0(0.00)$ & $0(0.00)$ & & & \\
\hline Left anterior descending (LAD) & $74(42.05)$ & $85(44.97)$ & $165(40.24)$ & $156(40.00)$ & $84(50.91)$ & $64(38.10)$ & & & \\
\hline Left circumflex (LCX) & $26(14.77)$ & $24(12.70)$ & $54(13.17)$ & 46 (11.79) & $22(13.33)$ & 37 (22.02) & & & \\
\hline Right circumflex (RCA) & $76(43.18)$ & $77(40.74)$ & $188(45.85)$ & 185 (47.44) & $58(35.15)$ & $67(39.88)$ & & & \\
\hline Saphenous vein graft & $0(0.00)$ & $2(1.06)$ & $2(0.49)$ & $2(0.51)$ & $1(0.61)$ & $0(0.00)$ & & & \\
\hline \multicolumn{10}{|c|}{ Angiographic and procedural characteristics } \\
\hline TIMI flow 0 to 2 before $\mathrm{PCI}, \mathrm{n}(\%)$ & $128(73.14)$ & $151(80.75)$ & $335(82.11)$ & 318 (82.17) & $123(74.55)$ & $137(82.04)$ & 0.63 & 0.10 & 0.25 \\
\hline Thrombus aspiration, $\mathrm{n}(\%)$ & $121(68.75)$ & $126(66.67)$ & $279(68.05)$ & $260(66.67)$ & $95(57.58)$ & $95(56.55)$ & 0.004 & 0.54 & 0.99 \\
\hline Multivessel treatment, n (\%) & $0(0.00)$ & $1(0.53)$ & $23(5.61)$ & $10(2.56)$ & $5(3.03)$ & $5(2.98)$ & 0.027 & 0.07 & 0.29 \\
\hline Treatment of LAD, n (\%) & $74(42.05)$ & $85(44.97)$ & 169 (41.22) & $159(40.77)$ & $85(51.52)$ & $64(38.10)$ & 0.78 & 0.34 & 0.07 \\
\hline \multicolumn{10}{|l|}{ Lesions and stenting } \\
\hline No. of lesions treated & $1.02 \pm 0.18$ & $1.03 \pm 0.19$ & $1.26 \pm 0.50$ & $1.23 \pm 0.47$ & $1.24 \pm 0.47$ & $1.23 \pm 0.46$ & $<0.001$ & 0.43 & 0.88 \\
\hline Total stent length $(\mathrm{mm})$ & $16.44 \pm 2.05$ & $16.37 \pm 2.19$ & $31.04 \pm 15.17$ & $29.54 \pm 13.58$ & $32.62 \pm 15.17$ & $32.89 \pm 12.68$ & $<0.001$ & 0.20 & 0.46 \\
\hline Maximum stent diameter (mm) & $3.36 \pm 0.34$ & $3.34 \pm 0.34$ & $3.27 \pm 0.42$ & $3.25 \pm 0.44$ & $2.94 \pm 0.50$ & $2.89 \pm 0.46$ & $<0.001$ & 0.22 & 0.86 \\
\hline No. of stents implanted & $1.00 \pm 0.00$ & $1.00 \pm 0.00$ & $1.50 \pm 0.70$ & $1.45 \pm 0.67$ & $1.55 \pm 0.74$ & $1.63 \pm 0.72$ & $<0.001$ & 0.66 & 0.26 \\
\hline Direct stenting, n (\%) & 132 (76.74) & $141(79.66)$ & $240(59.70)$ & $224(58.03)$ & $79(47.88)$ & 69 (41.32) & $<0.001$ & 0.54 & 0.44 \\
\hline Overlapping stents, n (\%) & $0(0.00)$ & $0(0.00)$ & $136(33.17)$ & $125(32.05)$ & $62(37.58)$ & $81(48.21)$ & $<0.001$ & 0.60 & 0.07 \\
\hline $\begin{array}{l}\text { Depicted are counts (\%) or means } \pm S D, p-p \\
\text { full-factorial models. Implanted stents cri } \\
\text { vessel diameter: } \geq 3.0 \mathrm{~mm} \rightarrow \text { maximum di } \\
\text { implanted. }\end{array}$ & es from ANOVA & logistic regr & ons (NICE group & inear, randomis & stent). * $p$-value & teraction NICE & isk group & ear) $\times s$ & $\begin{array}{l}\text { It from the } \\
\text { mplanted; large } \\
\text { length }\end{array}$ \\
\hline
\end{tabular}


Online Table 3. Medication use at procedure, discharge and follow-up of COMFORTABLE patients.

\begin{tabular}{|c|c|c|c|c|c|c|c|c|c|}
\hline \multirow[b]{2}{*}{ NICE risk factors } & \multicolumn{2}{|c|}{ None } & \multicolumn{2}{|c|}{ One } & \multicolumn{2}{|c|}{ Two or three } & \multicolumn{3}{|c|}{ p-values } \\
\hline & $\begin{array}{c}\text { DES } \\
N=148\end{array}$ & $\begin{array}{c}\text { BMS } \\
N=161\end{array}$ & $\begin{array}{c}\text { DES } \\
N=320\end{array}$ & $\begin{array}{c}\text { BMS } \\
N=319\end{array}$ & $\begin{array}{c}\text { DES } \\
N=107\end{array}$ & $\begin{array}{c}\text { BMS } \\
N=102\end{array}$ & NICE & Stent & $\begin{array}{l}\text { NICE } \mathrm{x} \text { stent } \\
\text { interaction }\end{array}$ \\
\hline \multicolumn{10}{|l|}{ During primary PCI } \\
\hline Aspirin*, n (\%) & $147(100.00)$ & $161(100.00)$ & $317(99.06)$ & $315(99.06)$ & $107(100.00)$ & $101(99.02)$ & 0.36 & 0.72 & \\
\hline Clopidogrel $^{*}, n(\%)$ & $124(84.35)$ & $137(85.09)$ & $257(80.31)$ & $253(79.31)$ & $90(84.11)$ & $81(79.41)$ & 0.29 & 0.62 & 0.73 \\
\hline Prasugrel $^{*}, \mathrm{n}(\%)$ & $53(36.05)$ & $52(32.30)$ & $140(43.75)$ & $141(44.20)$ & $38(35.51)$ & $45(44.12)$ & 0.10 & 0.82 & 0.36 \\
\hline Any DAPT*, n (\%) & 146 (99.32) & $161(100.00)$ & $317(99.06)$ & $315(98.75)$ & $107(100.00)$ & $99(97.06)$ & 0.18 & 0.38 & \\
\hline Unfractionated heparin, $n(\%)$ & $137(92.57)$ & $144(89.44)$ & $279(87.19)$ & $288(90.28)$ & $94(87.85)$ & $91(89.22)$ & 0.34 & 0.52 & 0.34 \\
\hline Low molecular weight heparin, n (\%) & $8(5.41)$ & $3(1.86)$ & $7(2.19)$ & $12(3.76)$ & $4(3.74)$ & $4(3.92)$ & 0.94 & 0.97 & 0.14 \\
\hline Bivalirudin, $n(\%)$ & $12(8.11)$ & $19(11.80)$ & $49(15.31)$ & $37(11.60)$ & $13(12.15)$ & $11(10.78)$ & 0.48 & 0.48 & 0.27 \\
\hline Glycoprotein IIb/Illa antagonists, n (\%) & $81(54.73)$ & $78(48.45)$ & $149(46.56)$ & $146(45.77)$ & $46(42.99)$ & $42(41.18)$ & 0.032 & 0.43 & 0.73 \\
\hline \multicolumn{10}{|l|}{ At discharge } \\
\hline Aspirin, $n(\%)$ & $148(100.00)$ & $159(98.76)$ & $315(99.68)$ & $316(100.00)$ & $105(100.00)$ & $101(100.00)$ & 0.16 & 0.58 & \\
\hline Any DAPT, n (\%) & $148(100.00)$ & $157(97.52)$ & $314(99.37)$ & $316(100.00)$ & $105(100.00)$ & $101(100.00)$ & 0.05 & 0.43 & \\
\hline \multicolumn{10}{|l|}{ At 30 days } \\
\hline Aspirin, $n(\%)$ & $147(100.00)$ & $156(97.50)$ & 309 (99.04) & 309 (99.68) & 100 (99.01) & $100(100.00)$ & 0.28 & 0.76 & \\
\hline Any DAPT, $n(\%)$ & $147(100.00)$ & $153(95.63)$ & 308 (98.72) & 307 (99.03) & $99(98.02)$ & $99(99.00)$ & 0.38 & 0.24 & 0.78 \\
\hline \multicolumn{10}{|l|}{ At one year } \\
\hline Aspirin, $n(\%)$ & 138 (98.57) & 146 (95.42) & 297 (98.02) & $288(96.64)$ & $94(94.95)$ & $90(96.77)$ & 0.58 & 0.22 & 0.30 \\
\hline Any DAPT, $n(\%)$ & 129 (92.14) & $128(83.66)$ & $274(90.43)$ & $269(90.27)$ & $85(85.86)$ & $81(87.10)$ & 0.87 & 0.25 & 0.16 \\
\hline $\begin{array}{l}\text { Depicted are counts (\%) or means } \pm S D, p- \\
\text { *Loading dosage or already on daily dosag } \\
<3.0 \mathrm{~mm} \rightarrow \text { maximum diameter of stents } \\
\text { implanted; short lesion length: }<20 \mathrm{~mm}-\end{array}$ & $\begin{array}{l}\text { ues from ANOV } \\
\text { or ASA, clopido }\end{array}$ & r logistic regre & ons (NICE grol & near, randomis & stent). DAPT wa & ASA with clopi & sel or pr & grel in C & $\begin{array}{l}\text { AFORTABLE. } \\
\text { sel diameter: } \\
\text { ength }\end{array}$ \\
\hline
\end{tabular}

Online Table 4. Medication use at procedure, discharge and follow-up of EXAMINATION patients.

\begin{tabular}{|c|c|c|c|c|c|c|c|c|c|}
\hline \multirow{3}{*}{ NICE risk factors } & \multicolumn{2}{|c|}{ None } & \multicolumn{2}{|c|}{ One } & \multicolumn{2}{|c|}{ Two or three } & \multicolumn{3}{|c|}{$p$-values } \\
\hline & DES & BMS & DES & BMS & DES & BMS & \multirow{2}{*}{ NICE } & \multirow{2}{*}{ Stent } & \multirow{2}{*}{$\begin{array}{l}\text { NICE } x \text { stent } \\
\text { interaction }\end{array}$} \\
\hline & $\mathrm{N}=176$ & $N=189$ & $\mathrm{~N}=410$ & $N=390$ & $\mathrm{~N}=165$ & $N=168$ & & & \\
\hline \multicolumn{10}{|l|}{ During primary PCI } \\
\hline Aspirin*, n (\%) & $164(93.18)$ & $174(92.06)$ & $375(91.46)$ & $357(91.54)$ & 155 (93.94) & $163(97.02)$ & 0.16 & 0.71 & 0.40 \\
\hline 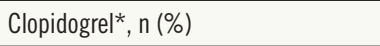 & $167(94.89)$ & $172(91.01)$ & 391 (95.37) & $371(95.13)$ & 154 (93.33) & $163(97.02)$ & 0.16 & 0.80 & 0.11 \\
\hline Any DAPT*, n (\%) & $161(91.48)$ & $165(87.30)$ & 370 (90.24) & 350 (89.74) & $148(89.70)$ & $160(95.24)$ & 0.16 & 0.97 & 0.07 \\
\hline Unfractionated heparin, $n(\%)$ & 145 (82.39) & $154(81.48)$ & $328(80.00)$ & $308(78.97)$ & $126(76.36)$ & $128(76.19)$ & 0.07 & 0.71 & 0.98 \\
\hline Low molecular weight heparin, n (\%) & $13(7.39)$ & $17(8.99)$ & $33(8.05)$ & $33(8.46)$ & $16(9.70)$ & $21(12.50)$ & 0.19 & 0.40 & 0.85 \\
\hline Bivalirudin, n (\%) & $16(9.09)$ & $13(6.88)$ & $21(5.12)$ & $31(7.95)$ & $12(7.27)$ & $12(7.14)$ & 0.68 & 0.46 & 0.26 \\
\hline Glycoprotein IIb/Illa antagonists, n (\%) & $73(41.48)$ & $78(41.27)$ & $160(39.02)$ & $146(37.44)$ & $57(34.55)$ & $55(32.74)$ & 0.036 & 0.61 & 0.97 \\
\hline \multicolumn{10}{|l|}{ At discharge } \\
\hline Aspirin, $n(\%)$ & $175(100.00)$ & $186(100.00)$ & 404 (98.78) & 385 (99.23) & 162 (99.39) & $166(98.81)$ & 0.16 & 0.77 & 0.43 \\
\hline Any DAPT, n (\%) & $175(100.00)$ & $186(100.00)$ & $404(98.78)$ & $384(99.22)$ & $160(98.77)$ & $166(98.81)$ & 0.08 & 0.57 & 0.73 \\
\hline \multicolumn{10}{|l|}{ At 30 days } \\
\hline Aspirin, $n(\%)$ & 160 (99.38) & $171(99.42)$ & 370 (98.14) & 357 (98.89) & $144(97.96)$ & $154(99.35)$ & 0.39 & 0.23 & 0.82 \\
\hline Any DAPT, n (\%) & 160 (99.38) & 171 (99.42) & 367 (97.09) & $353(98.06)$ & $142(96.60)$ & $154(99.35)$ & 0.18 & 0.12 & 0.53 \\
\hline \multicolumn{10}{|l|}{ At one year } \\
\hline Aspirin, $n(\%)$ & 145 (97.32) & 168 (99.41) & $370(97.63)$ & $342(98.56)$ & $143(97.28)$ & $151(96.79)$ & 0.23 & 0.26 & 0.42 \\
\hline Any DAPT, n (\%) & 142 (94.67) & 154 (91.12) & 366 (96.57) & 304 (87.61) & $142(96.60)$ & 137 (87.82) & 0.74 & $<0.001$ & 0.29 \\
\hline $\begin{array}{l}\text { Depicted are counts }(\%) \text { or means } \pm \text { SD, } \\
\text { or already on daily dosage for ASA and cl } \\
\text { diameter of stents implanted; large vess } \\
<20 \mathrm{~mm} \rightarrow \text { total stent length implanted. }\end{array}$ & lues from ANO & $\begin{array}{l}\text { S or logistic reg } \\
\text { stents criteria (i } \\
\rightarrow \text { maximum di }\end{array}$ & sions (NICE gro & linear, random & d stent). DAPT & S ASA with clop & grel in $\mathrm{E}$ & $\begin{array}{l}\text { AMINATION } \\
3.0 \mathrm{~mm} \rightarrow\end{array}$ & $\begin{array}{l}\text { *Loading dosage } \\
\text { maximum } \\
\text { lesion length: }\end{array}$ \\
\hline
\end{tabular}




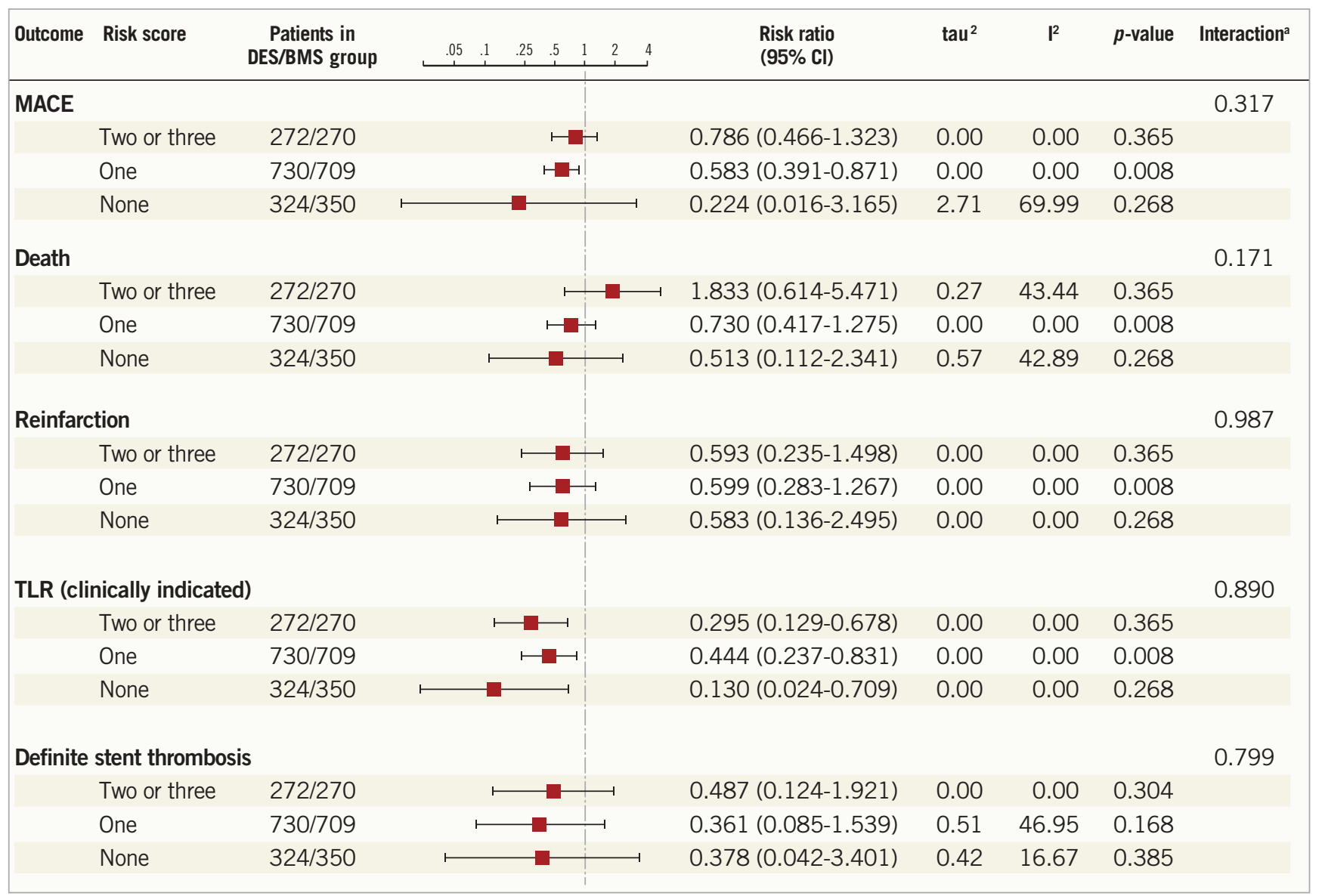

Online Figure 1. Pooled analysis of clinical endpoints according to stent used in the three risk score groups. p-values random effects using separate meta-analyses per outcome and risk score. ${ }^{a}$ p-values from test for trend over NICE risk factors using separate meta-regressions per outcome. 


\begin{tabular}{|c|c|c|c|c|c|c|c|}
\hline Outcome & $\begin{array}{l}\text { Events } \\
\text { DES }\end{array}$ & $\begin{array}{l}\text { Events } \\
\text { BMS }\end{array}$ & $\begin{array}{lllllll}.05 & .1 & .25 & .5 & 1 & 2 & 4 \\
\end{array}$ & $\begin{array}{l}\text { Risk ratio } \\
(95 \% \mathrm{Cl})\end{array}$ & $I^{2}$ & $p$-value $^{a}$ & $\begin{array}{c}p \text {-value } \\
\text { interaction }^{\mathrm{b}}\end{array}$ \\
\hline \multicolumn{8}{|l|}{ MACE } \\
\hline Diabetes - yes & $21 / 221$ & $21 / 211$ & $\mapsto$ & $0.96(0.54-1.70)$ & 0 & 0.875 & 0.029 \\
\hline Diabetes - no & $44 / 1,105$ & $90 / 1,118$ & $H-H$ & $0.50(0.35-0.71)$ & 0 & $<0.001$ & \\
\hline Small vessel - yes & $12 / 248$ & $25 / 265$ & $\longmapsto$ & $0.54(0.24-1.22)$ & 30 & 0.138 & 0.425 \\
\hline Small vessel - no & $53 / 1,078$ & $86 / 1,064$ & $\mapsto-$ & $0.59(0.34-1.03)$ & 62 & 0.064 & \\
\hline Long lesion - yes & $51 / 834$ & 74/800 & Het & $0.66(0.47-0.93)$ & 0 & 0.018 & 0.154 \\
\hline Long lesion - no & $14 / 492$ & $37 / 529$ & $\longmapsto$ & $0.35(0.11-1.13)$ & 56 & 0.080 & \\
\hline \multicolumn{8}{|l|}{ Death } \\
\hline Diabetes - yes & $17 / 221$ & $10 / 211$ & $\longrightarrow$ & $1.63(0.75-3.51)$ & 0 & 0.216 & 0.035 \\
\hline Diabetes - no & $27 / 1,105$ & $39 / 1,118$ & 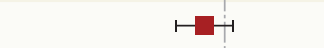 & $0.70(0.43-1.14)$ & 0 & 0.150 & \\
\hline Small vessel - yes & 7/248 & 6/265 & $\longmapsto$ & $1.23(0.42-3.62)$ & 0 & 0.706 & 0.266 \\
\hline Small vessel - no & $37 / 1,078$ & $43 / 1,064$ & $\mapsto$ & $0.85(0.55-1.31)$ & 0 & 0.458 & \\
\hline Long lesion - yes & $33 / 834$ & $31 / 800$ & $\mapsto$ & $1.02(0.63-1.65)$ & 0 & 0.934 & 0.175 \\
\hline Long lesion - no & $11 / 492$ & $18 / 529$ & $\longmapsto \square$ & $0.67(0.31-1.41)$ & 0 & 0.289 & \\
\hline \multicolumn{8}{|l|}{ Reinfarction } \\
\hline Diabetes - yes & $5 / 221$ & 10/211 & $\longmapsto-1$ & $0.50(0.17-1.44)$ & 0 & 0.197 & 0.359 \\
\hline Diabetes - no & $16 / 1,105$ & $26 / 1,118$ & $\mapsto-1$ & $0.62(0.34-1.16)$ & 0 & 0.138 & \\
\hline Small vessel - yes & $4 / 248$ & 9/265 & $\longmapsto$ & $0.48(0.15-1.56)$ & 0 & 0.221 & 0.345 \\
\hline Small vessel - no & $17 / 1,078$ & $27 / 1,064$ & $\mapsto$ & $0.63(0.34-1.15)$ & 0 & 0.131 & \\
\hline Long lesion - yes & $16 / 834$ & 25/800 & $\mapsto$ & $0.61(0.33-1.14)$ & 0 & 0.120 & 0.399 \\
\hline Long lesion - no & $5 / 492$ & $11 / 529$ & $\longmapsto-1$ & $0.52(0.18-1.53)$ & 0 & 0.236 & \\
\hline \multicolumn{8}{|l|}{ TLR } \\
\hline Diabetes - yes & $5 / 221$ & $14 / 211$ & $\longmapsto$ & $0.36(0.13-0.99)$ & 0 & 0.048 & 0.426 \\
\hline Diabetes - no & $17 / 1,105$ & $54 / 1,118$ & $\mapsto$ & $0.32(0.19-0.55)$ & 0 & $<0.001$ & \\
\hline Small vessel - yes & $5 / 248$ & $19 / 265$ & $\longmapsto$ & $0.30(0.10-0.88)$ & 12 & 0.028 & 0.419 \\
\hline Small vessel - no & 17/1,078 & $49 / 1,064$ & $\longmapsto$ & $0.35(0.18-0.67)$ & 29 & 0.002 & \\
\hline Long lesion - yes & $18 / 834$ & $48 / 800$ & $\mapsto$ & $0.36(0.21-0.61)$ & 0 & 0.000 & 0.309 \\
\hline Long lesion - no & 4/492 & $20 / 529$ & $\longmapsto$ & $0.25(0.06-0.98)$ & 20 & 0.047 & \\
\hline \multicolumn{8}{|c|}{ Definite stent thrombosis } \\
\hline Diabetes - yes & $3 / 221$ & $4 / 211$ & $\longmapsto$ & $0.76(0.15-3.88)$ & 0 & 0.737 & 0.167 \\
\hline Diabetes - no & $6 / 1,105$ & $22 / 1,118$ & $\longmapsto$ & $0.29(0.11-0.81)$ & 17 & 0.018 & \\
\hline Small vessel - yes & $1 / 248$ & 4/265 & $\longmapsto$ & $0.37(0.06-2.38)$ & 0 & 0.293 & 0.494 \\
\hline Small vessel - no & $8 / 1,078$ & $22 / 1,064$ & $\longmapsto$ & $0.36(0.16-0.81)$ & 0 & 0.013 & \\
\hline Long lesion - yes & $7 / 834$ & 19/800 & $\longmapsto$ & $0.36(0.09-1.49)$ & 57 & 0.158 & 0.462 \\
\hline Long lesion - no & 2/492 & $7 / 529$ & $\longmapsto$ & $0.41(0.04-4.26)$ & 47 & 0.456 & \\
\hline
\end{tabular}

Online Figure 2. Meta-analysis of clinical outcomes in presence of individual risk factors (lesion length, vessel size and diabetes) for DES vs. $B M S$ use. ${ }^{a} p$-values random effects using separate meta-analyses per outcome and per presence or absence of the risk factor; ${ }^{b} p$-values from a Z-test for the interaction between stent type and presence/absence of risk factor 